
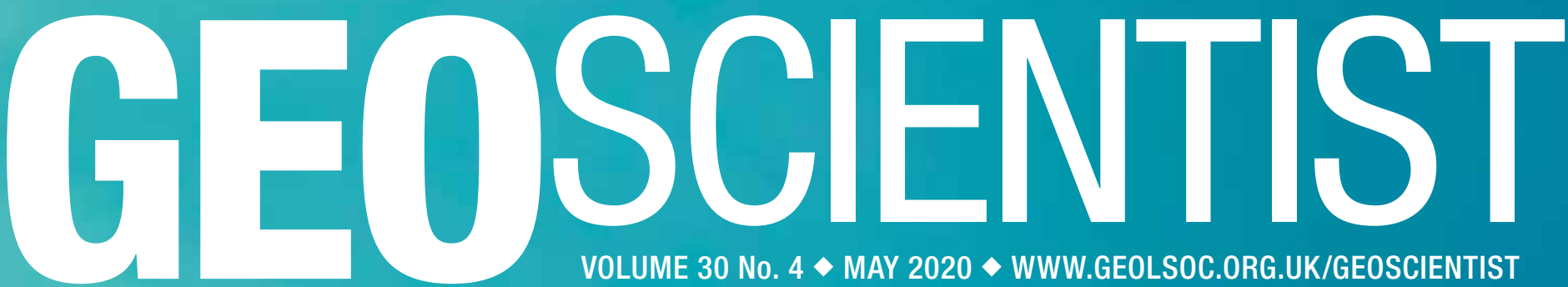

VOLUME 30 No. 4 • MAY $2020 \diamond$ WWW.GEOLSOC.ORG.UK/GEOSCIENTIST
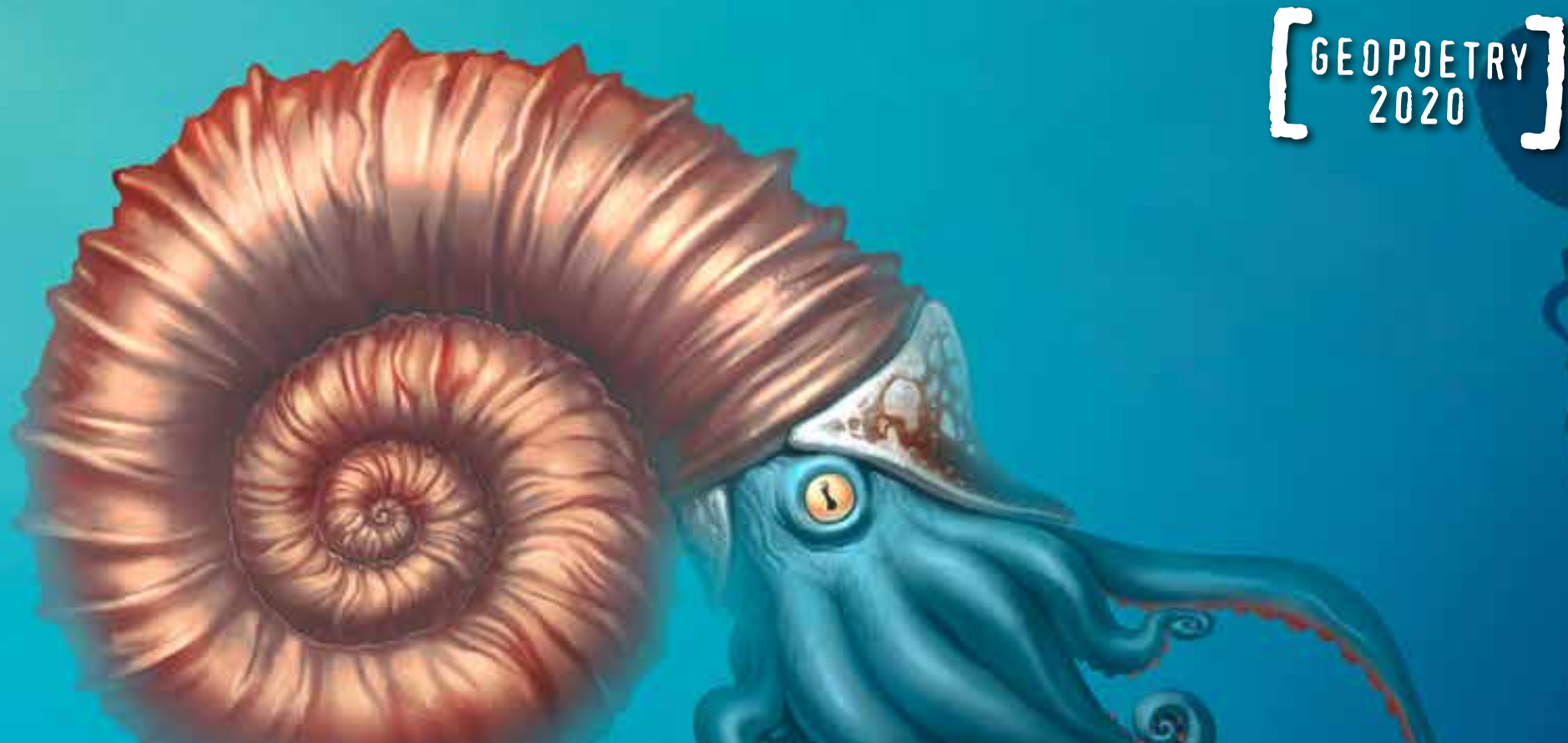

\title{
AMMONITES,
}

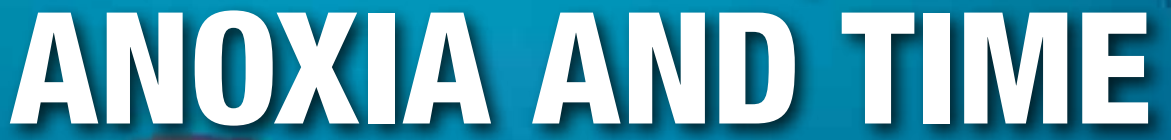

Kevin Page on how ammonites

can help us understand a crucial

moment in Earth's history

STAYING IN

Top tips for geologists working from home
WHY GEOPOETRY?

Poetry can help geologists reach more people, says Patrick Corbett
POETRY ON THE MOORS

The geological influences on Ted Hughes 

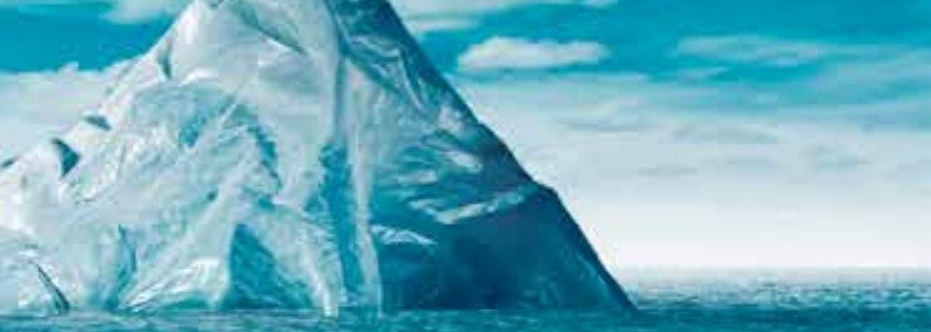

ron

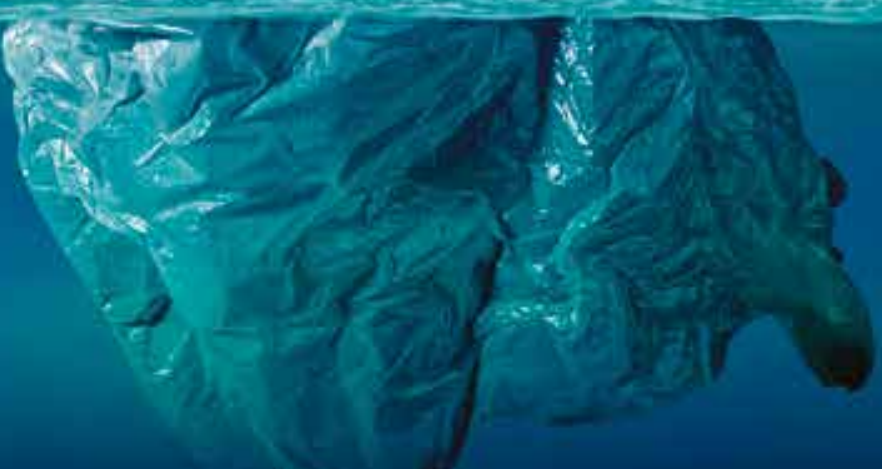

15 March 2021

\section{Plastics in the Environment}

The Geological Society, Burlington House, London

Pritiany Convenors

Wes Fraser (Oxford Brookes

University)

Gordon Inglis (University of

Southampton)

\section{Further information}

For further information about the, conference please contact:

conference Office,

The Geological Society,

Burlington House, Piccadilly,

London W1J OBG

T: 02074349944

E: conference@geolsoc.org.uk

Web:

www.geolsoc.org.uk/plastics2021

[2. Follow this event on Twitter: \#plastics2021
The accumulation of plastic debris in the environment is a global problem which may have detrimental impacts on ecosystem health. Plastics are now widely enough distributed that they may also act as an anthropogenic marker horizon in the future rock record. However, there are still many outstanding questions regarding the: 1) source, 2) transfer, 3) degradation, 4) persistence and 5) measurement of plastics in the environment.

This one-day meeting will bring together researchers from a diverse range of disciplines (e.g. hydrology, sedimentology, geochemistry, earth science, biology) to discuss the fate of plastics in terrestrial, freshwater and marine environments.

This meeting seeks to foster conversation between these different communities to facilitate a more holistic approach towards understanding plastic in the environment.

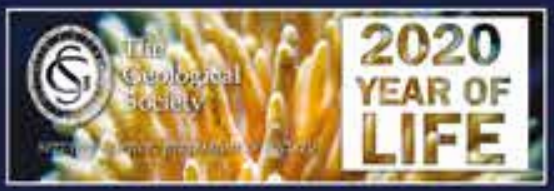


Geoscientist is the

Fellowship magazine of the Geological Society of London

The Geological Society, Burlington House, Piccadilly, London W1J OBG

T +44 (0)20 74349944 F +44 (0)20 74398975

E enquiries@geolsoc.org.uk (Not for Editorial

Please contact the Editor)

Publishing House

The Geological Society

Publishing House, Unit 7

Brassmill Enterprise Centre,

Brassmill Lane, Bath

BA1 3JN

T 01225445046

F 01225442836

\section{Library}

T +44 (0)20 74320999

E library@geolsoc.org.uk

EDITOR-IN-CHIEF

Professor Andy Fleet

DEPUTY EDITOR-IN-CHIEF

Mr David Shilston

EDITOR

Ms Sarah Day

E sarah.day@geolsoc.org.uk

EDITORIAL PANEL

Mrs Natalyn Ala

Mr Steve Branch

Dr Robin Cocks

Dr Howard Falcon-Lang

Dr Hazel Gibson

Prof. Tony Harris

Mr Edmund Nickless

Dr Alan Roberts

Prof. Peter Styles

Dr Colin Summerhayes

Prof. Frances Wall

Dr Jan Zalasiewicz

Trustees of the

Geological Society

fondon 2019-2020

Prof Nicholas Rogers (President

Mr Thomas Backhouse

Mr Andrew Bloodworth

Mr John Booth (Vice President

Dr Michael Daly

(President designate)

Ms Lesley Dunlop

Dr Joel Gill

Mr Graham Goffey (Treasurer)

Dr Kathryn Goodenough

Dr Sarah Gordon (Secretary,

Foreign \& External Affairs)

Prof James Griffiths

Prof Chris King

Mr Andrew Moore

Prof Bryne Ngwenya

Mr Nicholas Reynolds

(Vice President)

Prof Katherine Royse

(Secretary, Professional Matters)

Mrs Sarah Scott

Ms Gemma Sherwood

Miss Jessica Smith (Vice President)

Dr Helen Smyth

Prof Robin Strachan

(Secretary, Publications)

Mr John Talbot (Vice President)

Dr Alexander Whittaker

(Secretary, Science)

Published on behalf of

the Geological Society

of London by:

Century One Publishing

Alban Row, 27-31 Verulam Road

St Albans, AL3 4DG

T 01727893894

E enquiries@centuryone

publishing.uk

w www.centuryon

publishing.uk
ADVERTISING SALES

Dominic Arnold

T 01727739184

E dominic@centuryonepublishing.uk

Creative Director

Peter Davies

PRINTED BY

Century One Publishing Ltd.

Copyright

The Geological Society of London is a Registered Charity, number 210161.

SSN (print) 0961-5628

ISSN (online) 2045-1784

The Geological Society of London

accepts no responsibility for the views

expressed in any article in this publication.

All views expressed, except where explicity

tated othenise, represent those of

athor and not The Gelogical Society of

autho, and not The Geological Society of

London. All All rights reseved. No paragrap

of this publication may be reproduced,

copied or transmitted save with written

permission. Users registered with Copyright

Clearance Center. the Jounnal is registered

with CCC, 27 Congress Street, Salem, MA

01970, USA. Every effort has been made

to trace copyright holders of material in this

publication. If any rights have been omitted,

the publisher offer their apologies.

No responsibility is assumed by the

Publisher for any injury and/or damage to

persons or property as a matter of products

liability negligence or othenuise, or from

any use or operation of any methods,

products, instructions or ideas contained

in the material herein. All advertising

material is expected to conform to ethical

and trading standards, and reasonable

care is taken to ensure that advertisers are

reputable and reliable. However, inclusion

in this publication or as an insert does not

consitute a guarantee or endorsement

of the quality or value of such products

or services, or of the claims made by

its manufacturer. Geoscientist and the

Geological Society of London can give no

assurance that an advertiser will fulfil its

obligation under all circumstances.

Subscriptions: All correspondence

relating to non-member subscriptions

th

subcription Desses to the Jounals

Subscription Department, Geological -

Society Publishing House, Unit 7 Brassm

Enterprise Centre, Brassmill Lane, Ba

BA1 3JN, UK. Tel: 01225445046.

Email: sales@geolsoc.org.uk. Contact us

by phone or email for current rates.

(C) 2020 The Geological Society

of London

Geoscientist is printed on FSC ${ }^{\circledast}$ mixed

credit - Mixed source products are a blend

of FSC 100\%, Recycled and/or Controlled

Council ${ }^{\Theta}$

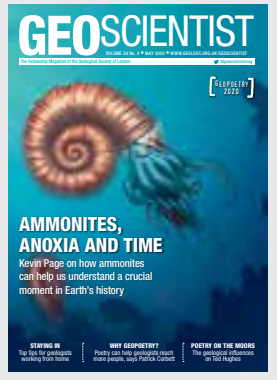

from Century One Publishing

\section{Crecycle}

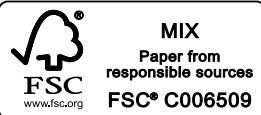

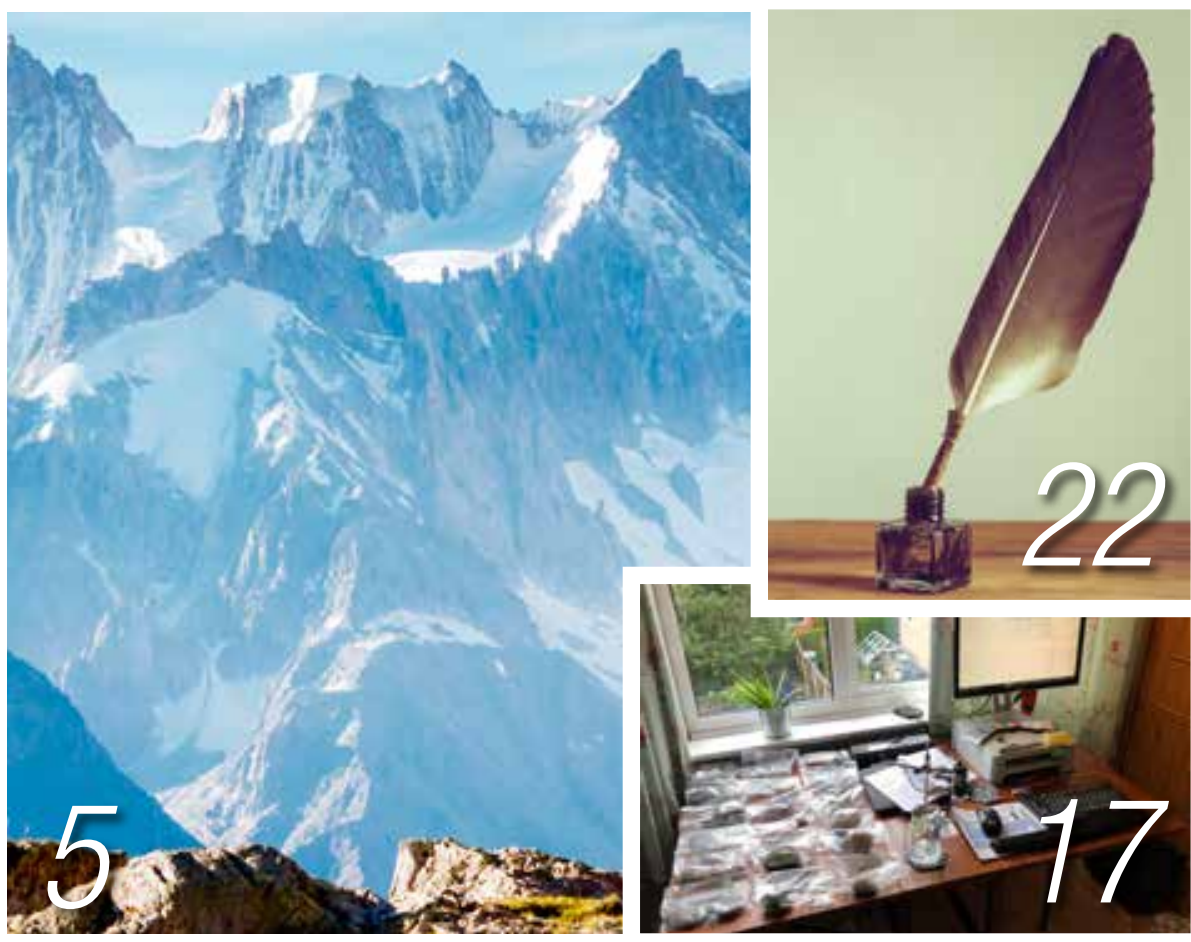

\section{ON THE COVER:}

10 AMMONITES, ANOXIA AND TIME

Kevin Page on how ammonites are

helping geologists to understand more about the chronology of Early Toarcian events, including the famed Toarcian Ocean Anoxic Event

\section{MEETING REPORT}

\section{ON THE MOORS WITH TED HUGHES AND OVID}

Mike Stephenson recounts a recent walk with the Yorkshire Geological Society which revealed links between poetry and geology

\section{REGULARS}

05 WELCOME A homage to the great outdoors

06 SOCIETY NEWS What your Society is doing at home and abroad

08 SOAPBOX Geology is too important to be left to geologists, argues Patrick Corbett ahead of Geopoetry 2020

17 CAREERS Clive Mitchell's top tips for working from home

18 BOOK REVIEWS Six new books reviewed

21 LETTERS Working remotely, and a response to last month's Soapbox

24 PEOPLE Nina Morgan on the lesser known side of John Ruskin and an update from the Mary Anning Rocks campaign

29 OBITUARY lain Ashworth Williamson (1931-2019) \& Alastair Charles Lumsden (1937-2019) 


\section{Operations Geology in 2020 and Beyond:} Traditional and modern approaches 4-5 November 2020

The Geological Society, Burlington House, Piccadilly, London

Convenors:

\section{David Baldwin}

Genel Energy

Mariël Reitsma HRH Geology

\section{Pramit Basu}

Baker Hughes

Alex Edwards

Ikon Science

\section{Brian Hodgson} Shell

Rachael Horton BP

Tim Stephen Aker BP

Jenny Windress Ithaca Energy

Event Sponsors:

Sponsorship opportunities available.
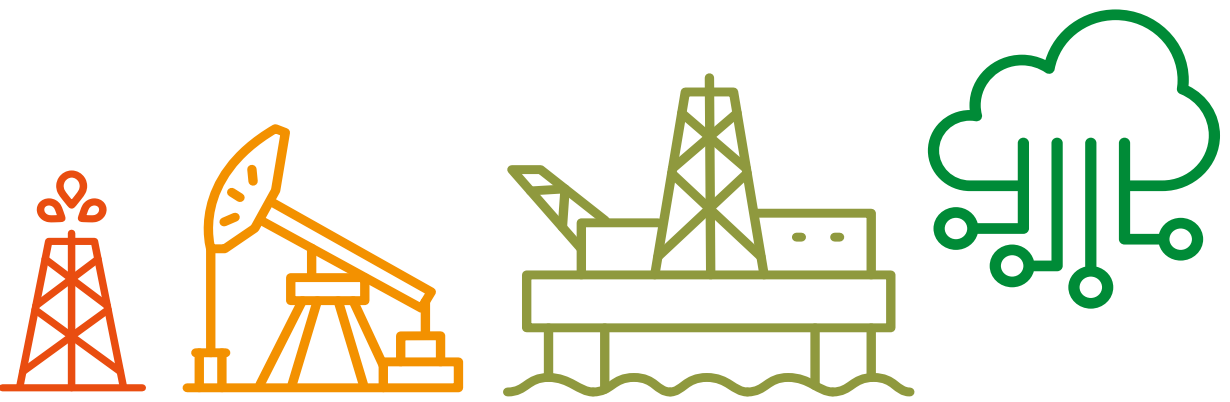

The key theme of the 5th Operations Geoscience conference is how the role of the Operations Geologist will evolve as the Oil \& Gas industry embraces the digital transformation. Operations Geologists will be at the heart of this transformation by bringing together digitalisation and geological expertise to improve operational efficiency and prom te success.

The organisers invite contributions within all aspects of Operations Geoscience with a preferred focus on emerging technologies and advances in the digital oilfield.

Suggested themes include:

- Machine learning and artificial intelligence applied to planning and drilling a well

- Digitalisation and "disrupting" current work flows - can digitalisation and data mining generate additional information that will change the role of the operations geoscientist?

- New analytical technologies and technological advances - case studies of e.g. LWD, wireline or modelling solutions as applied during operations

- PPFG, Geomechanics \& surface logging showcasing innovative approaches and surprising outcomes

- Managing risks and improving safety

Keynote speakers to be announced soon. A parallel poster session will take place in the library during the breaks.

An informal social event will be held at BrewDog Seven Dials on the evening of Wednesday 4th November 2020.

For further information and abstract submission please contact:

Abstract Guidelines available on the conference website www.geolsoc.org.uk/11-pg-opsgeology-2020

Sarah Woodcock, The Geological Society, Burlington House, Piccadilly, London W1J 0BG.

Tel: +44 (0)2074349944 or email: sarah.woodcock@geolsoc.org.uk 


\section{THE GREAT OUTDOORS}

n 1802, a young English traveller stood in a Swiss valley gazing up at Mont Blanc. In his notebook, he wrote 'To gain a just delineation of a Swiss view the artist should consult his feelings as much as his sight...the tranquility of the Evening, the beautiful tints of the setting sun, the grandeur of the mountain had thrown me into such a mood which it is impossible to describe and rendered me in the highest degree susceptible of pleasure.'

You'd be forgiven for guessing that our mountaineer might be a romantic poet composing verses - Wordsworth, perhaps, or Coleridge. The Swiss Alps were a kind of rite of passage for poets and thinkers of the time - everyone seemed to be making the trip and composing verses, no doubt of varying quality, afterwards.

In this case, however, the author was none other than the Geological Society's first President, George Bellas Greenough (1778-1855). Five years after that scene in the Alps, Greenough would be part of the group of thirteen men forming 'a little talking geological Dinner Club' of like-minded friends.

Greenough isn't exactly remembered now as a romantic figure, wandering about on hills and outcrops feeling poetical. If you think of him at all, it's probably as a key player in the Geological Society's poor treatment of William 'Strata' Smith, and the creator of the Society's own geological map of the nation published 200 years ago this year - which now hangs beside Smith's at Burlington House.

Here's what Coleridge had to say about Greenough, after a meeting in Gottingen in 1801: 'I loved and esteemed you more than any I met there.' When Coleridge took a trip to Malta in 1805 , Greenough sent him off with a packet of dried soup, a bottle of brandy and a copy of Hauy's 'Mineralogy', 'packed up with Greenough's neatness in one parallelogram of brown paper!'

Many poets and scientists in the early nineteenth century, as this months' Soapbox reminds us, were engaged in lively discourse that might seem unusual to us now. There are lots of reasons for this, but perhaps, for geologists in particular, one of them is simply a love of the outdoors. 'Surely there are times', wrote Greenough in 1802, 'when it is permitted to absent ourselves from the realities of life to indulge in reveries?'

It's been hard, over the last few weeks, to indulge in reveries. For many of us, a geological career began with a love of the outdoors; a place which a few weeks ago became virtually inaccessible. It's hard to know what the situation will be by early May, when you read this, but many of us are likely to still be spending much of our time working at home - this month, Clive Mitchell offers some tips that might help you through.

Our meeting report - usually accounts of conferences and workshops held indoors - comes this month from the Yorkshire Moors, as Mike Stephenson recounts a walk with the Yorkshire Geological Society in which the poetry of Ted Hughes and Ovid takes on new meaning. Our feature, too, is a reminder of how much geology takes place in the open air - in this case, on the site of an outcrop yielding exciting finds which could help us to better understand the Toarcian.

I hope you enjoy this month's issue, particularly if it comes at a time when you're unable to spend much time outside yourself. Most of all, I hope it finds you safe and well, and that we'll all be outside again before too long. (Composition of dubious verses is optional.)

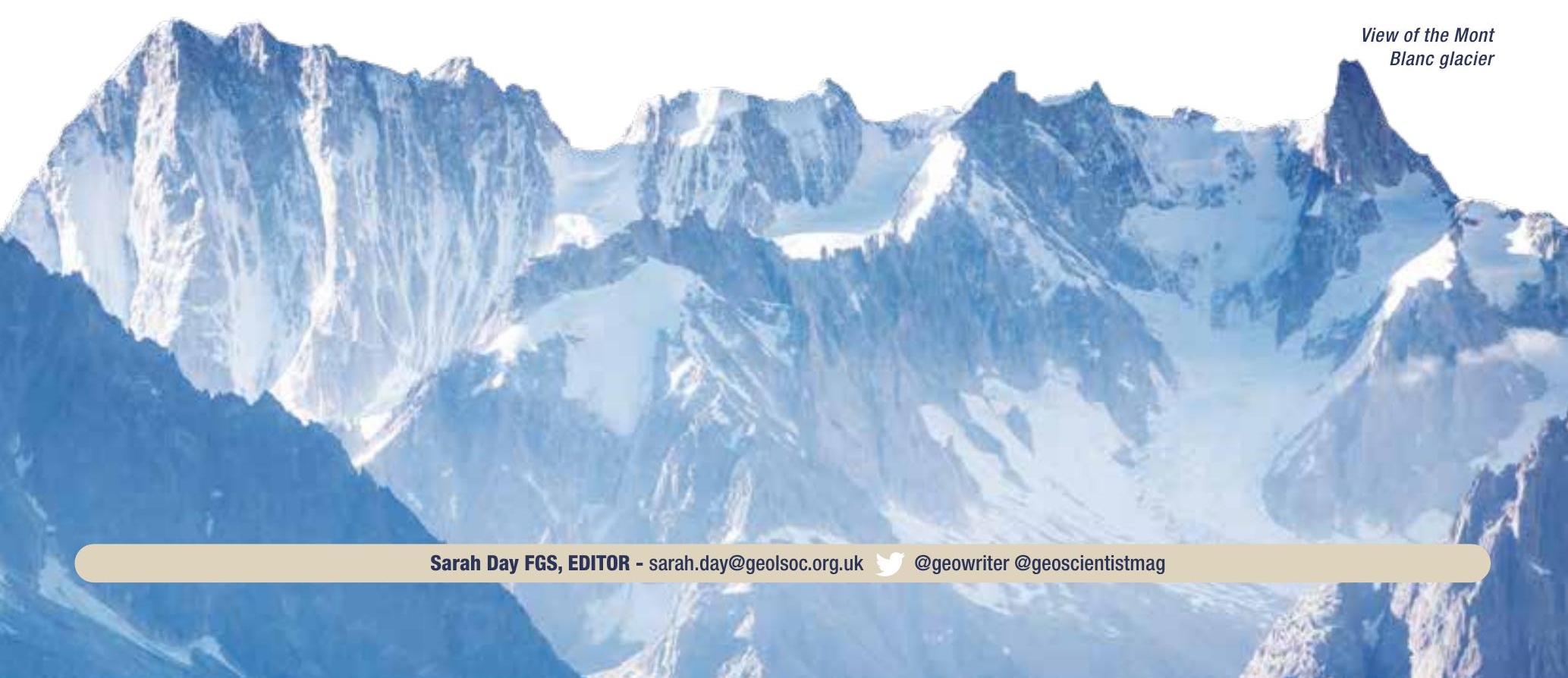




\section{SOCIETYNEWS}

\section{PRESIDENT'S DAY}

At the time of writing, Burlington House is closed because of the Covid-19 pandemic. It is unlikely that President's Day or the AGM will be conducted in person on 4 June, however further details of the arrangements will be communicated once a final decision has been made. In the meantime, in line with bye-law 9.2, the agenda for the AGM is presented as follows:-

\section{AGM Agenda}

Apologies

Minutes of the Annual General Meeting held on 6 June 2019

Appointment of Scrutineers for the ballots for Council and Officers Ballot for Council

Annual Report and Accounts for 2019

$$
\begin{aligned}
& \text { - President's Report } \\
& \text { - Secretaries' Reports } \\
& \text { - Treasurer's Report }
\end{aligned}
$$

Comments from Fellows

Report of Scrutineers on the ballot for Council

Ballot for Officers

Fellowship subscriptions for 2021

Deaths

Appointment of Auditors

Report of Scrutineers on the ballot for Officers

Any other business

Provisional date of next Annual General Meeting - 10 June 2021

\section{CORONAVIRUS UPDATE}

Due to the rapidly evolving government advice around travel and public gatherings, the Geological Society and our regional and specialist groups have postponed many lectures and conferences in May. Please check our events page (https://www. geolsoc.org.uk/events) for up-to-date information. The Society's offices were closed throughout April - please check online for the latest updates.

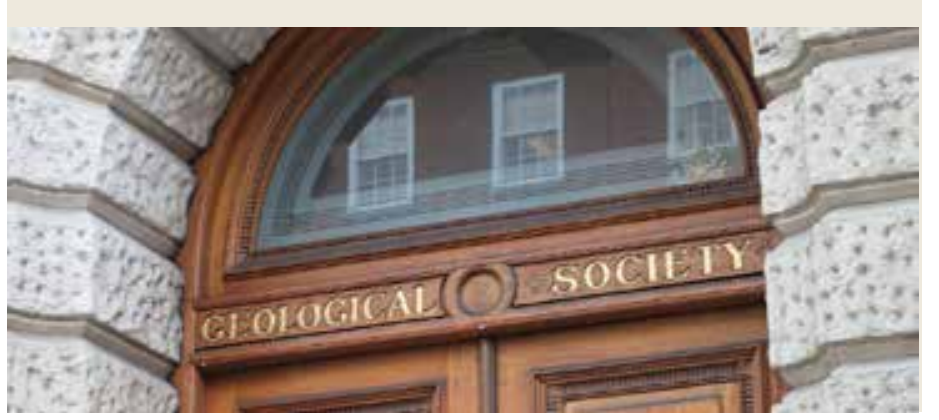

\section{ELECTION RESULTS}

The advisory ballot for Council, conducted by Civica Election Services, closed on 31 March. The turnout was 17.6\%. A total of 2,056 valid votes were cast for the five vacancies on Council. The results were as follows:

\begin{tabular}{lcc} 
& Votes & $\%$ of valid voters \\
ALEXANDER, Joanna & 1,349 & $65.6 \%$ \\
WILLIAMS, Lucy & 1,199 & $58.3 \%$ \\
KEHINDE, Michael & 1,195 & $58.1 \%$ \\
PERRY, John & 1,004 & $48.8 \%$ \\
GILBERT, Jennie & 952 & $46.3 \%$ \\
\hline LATIN, David & & \\
LAWRENCE, James & 927 & $45.1 \%$ \\
\end{tabular}

The five candidates receiving the most votes will go forward to the Annual General Meeting for election as Council members.

\section{ANNUAL FELLOWSHIP SUBSCRIPTIONS}

Since 2015 the annual increase in Fellowship Fees has been set with reference to the prevailing annual rate of Consumer Price Index (CPI) inflation when proposals are considered for the following year in March and April. The rate of CPI for January 2020 was $1.8 \%$.

At its meeting on 8 April Council agreed to recommend to the Fellowship for approval at the Annual General Meeting the subscription rates for 2021 shown below. In addition, it is proposed, at the request of the Chartership Committee and agreed by the Finance \& Planning Committee, to reduce the CGeol supplement fee from £50 to £20 for retired Chartered Geologists.

Junior Candidate Fellow Candidate Fellow

27 and under

28-33

$34-59$

34-59 (Overseas)

$60-64$

65-69

$70+$

Concessions

Full time postgraduate MSc

Full time postgraduate $\mathrm{PhD}$

Joint Fellowship fee

CGeol supplement payers

CGeol supplement payers (retired)
2020

$£ 10.00$

$£ 15.00$

$£ 75.00$

$£ 140.00$

$£ 214.00$

$£ 164.00$

$£ 140.00$

$£ 107.00$

$£ 73.00$

$£ 75.00$

$£ 31.00$

$£ 44.00$

$£ 139.50$

$£ 50.00$

$£ 50.00$
2021

$£ 10.00$

$£ 15.00$

$£ 76.00$

$£ 143.00$

$£ 218.00$

$£ 167.00$

$£ 143.00$

$£ 109.00$

$£ 74.00$

$£ 76.00$

$£ 32.00$

$£ 45.00$

$£ 142.00$

$£ 50.00$

$£ 20.00$ 


\section{FUTURE MEETING DATES}

OGMs: 17 June 2020, 8 September 2020, 25 November 2020, 27 January 2021, 7 April 2021

Council: 17 June 2020, 8 \& 9 September 2020 (residential) 25 November 2020, 27 January 2021, 7 April 2021

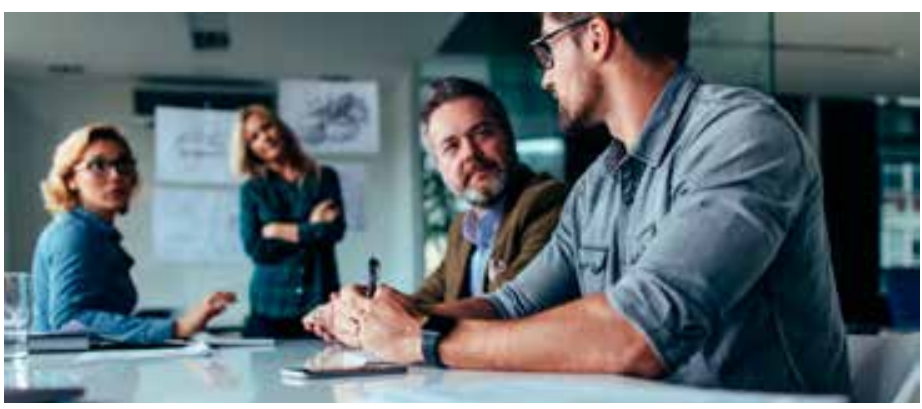

\section{OFFICERS FOR 2020/2021}

At the AGM Fellows will be asked to elect the following members of Council as Officers for 2020/21:

President: Dr Michael Daly

Vice-Presidents: Mr John Booth, Mr Nicholas Reynolds, Miss Jessica Smith Secretaries: Prof James Griffiths, Prof Robin Strachan, Dr Alexander Whittaker

Secretary, Foreign \& External Affairs: Dr Joel Gill

Treasurer: Mr Graham Goffey

\section{POLICY UPDATE}

The Geological Society has published a new policy briefing note on 'Geological Disposal of Radioactive Waste' relating to the UK Government's commitment to developing a deep geological disposal facility for the UK's radioactive waste.

The briefing note explains what deep geological disposal of radioactive waste is and why the UK Government has opted for this approach, as well as outlining the ways in which geology will enable a disposal facility to provide safety and security for waste in the long term. It also outlines the policy background to the Government's commitment, as well as the history of radioactive waste generation and management in the UK until present.

Information about how a geological disposal facility will be located and constructed is provided along with case studies from around the world where geological disposal of radioactive waste is planned or taking place.

You can read the new policy briefing note at www.geolsoc.org.uk/ policy_statements.

\section{FROM THE LIBRARY}

The GSL Library staff are here to support our Fellows, Friends, Corporate Patrons and other researchers, including during periods where our building is closed. For more information about Library services or if you have any enquiries visit www.geolsoc.org.uk/library, email library@geolsoc.org.uk or call us on 02074320999

\section{E-journals and e-books}

Fellows can access $100+$ e-journals and $60+$ e-books for free using Athens logins. Find out more and see what's available at www.geolsoc.org.uk/VirtualLibrary

If you've not signed up for an Athens account please download and email us the registration form from www. geolsoc.org.uk/AthensAccess or contact us on library@ geolsoc.org.uk

\section{Online Library and Archive catalogues}

Search the online catalogue of books, journals and maps held in the Geological Society Library and explore our archive collection:

www.geolsoc.org.uk/librarycatalogue geolsocarchives.org.uk

\section{Looking for information? Get in touch}

- Research/Enquiries - as well as helping with the Library's electronic resources we can advise where to find material. We are able to access some resources in addition to what you might find yourself online

- Inter-Library loans - if you would like to borrow a book or access a paper from a journal we don't subscribe to, please let us know and we will try and source it from elsewhere. Just ask!

- Database searches - we can search the GeoRef and Geofacets databases on your behalf and send you lists of references

- Maps - the Map Librarian can offer advice and direct you to free online mapping where available

\section{Picture Library}

Discover hundreds of images from our historical collections on our Picture Library. Whether it's the fossils discoveries of Mary Anning, beautiful geological maps, or even the world's largest pearl, there is something for everyone! www.gslpicturelibrary.org.uk

\section{Online exhibitions}

The Library's online exhibitions highlight various treasures from the Geological Society's special collections, and shed light on some of the most important figures in the history of geology. www.geolsoc.org.uk/Library-and-InformationServices/Exhibitions 


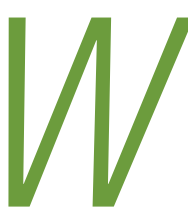

e're used to hearing that the planet is under threat, but what does that really mean? The planet itself is surely safe - what is under threat are species and people. We can try our best to control geological processes, but - as we are constantly reminded by events like flooding, earthquakes, tsunamis and sea level change - it seems the geology is always in charge.

So why don't people appreciate this more? It may be that they don't read textbooks, and I doubt this will change. The answer is perhaps that we need more use of the poetry of geoscience - or geopoetry. Poems 'make one feel, but also understand. They inspire and upset, they provoke and reflect' (Parkinson, 2019).

\section{GEOLOGY IN POETRY}

Geology and geologists have featured in poetry for centuries. William Wordsworth's poem Excursion (1814) contains an early reference to the geologist in the lines 'He who with pocket-hammer smites the edge/of luckless rock or prominent stone, disguised/In weather stains or crusted o'er by Nature/The substance classes by some barbarous name/and thinks himself enriched,/Wealthier and doubtless wiser than before.'

The late 19th Century saw a flowering of geopoetry at a time when debates between scientists and artists were commonplace. Whilst poets such as Keats worried that science would 'steal away some of the magic from the world' (Illingworth, 2019), the geologist was clearly entering the consciousness - perhaps following on from the creation of the Geological Society of London in 1807.

That interest hasn't waned. For example, Mike Stephenson has visited the Yorkshire sites that inspired Ted Hughes, and knowledge of geology as well as poetry draws out new meaning in some of his poems. Hughes's take on Millstone Grit is perhaps captured in the lines '... big animal of rock' and '... kneeling in the cemetery of its ancestors'.

And Sarah Acton notes in reflections of our totemic Jurassic Coast (Acton, 2017): 'this cliff is lone ranger, our frontier messenger/carrying
DNA for earth revival, should/the next extinction allow survival'.

\section{GEOPOETRY 2020}

Discussion between scientists and artists took centre stage at a 2011 Geological Society event, 'Poetry and Geology: A Celebration.' The Society, in conjunction with the Central Scotland Group, is currently organising 'Geopoetry 2020' with the Scottish Poetry Library and the Edinburgh Geological Society, to be held on 1 October.

Geopoetry 2020 is an opportunity for all those interested in geology and poetry to get together to discuss the interplay between the two. Coming before COP26 in Glasgow (assuming both are able to go ahead in these uncertain times), it would be nice to see submissions to the former that could also be presented as part of the latter, to enable reflection on geologists' feelings for our planet. Poetry and geological sciences have drifted apart - is it time for a reconvergence?

\section{A GEOPOETIC FUTURE}

Poetry is an opportunity to communicate with a wider group of people in different forums. Geologists must enter this space, for fear of missing out. What reaches people is not the weighty technical details of lithology, stratigraphy, taxonomy, sedimentology, geomechanics, geochemistry - but fears of the underworld, love of birds, care for the planet. Few can possibly be interested in whether Top Palaeocene is 56.6 or 55.5 Mya - but they might be interested in the origins of the Palaeo-Eocene Maximum. Whilst poets write on the Anthropocene, geologists work globally to define its precise start date.

Wake up, fellow geologists - the wider public is worried about the planet. We must learn to communicate better in their language, not just in ours.

A fuller version of this article, 'Why Geopoetry?' can be read online

Patrick Corbett is Heriot-Watt University Poet for 2020 and welcomes geopoetic contributions (p.w.m.corbett@hw.ac.uk).

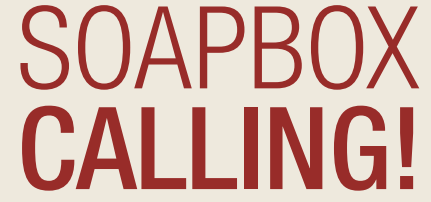

Soapbox is open to contributions from all Fellows. You can always write a letter to the Editor, of course, but perhaps you feel you need more space?

If you can write it entertainingly in 500 words, the Editor would like to hear from you. Email your piece, and a self-portrait, to sarah.day@geolsoc.org.uk. Copy can only be accepted electronically. No diagrams, tables or other illustrations please.

Pictures should be of print quality - please take photographs on the largest setting on your camera, with a plain background.

Precedence will always be given to more topical contributions. Any one contributor may not appear more often than once per volume (once every 12 months).

Geopoetry 2020 is due to take place on 1 October 2020 at the Edinburgh Poetry Library. Submissions are open until 31 May 2020 - for further information, please visit www.geolsoc.org.uk/ geopoetry20

\section{References}

Acton, Sarah 'Jurassic Coast Poems, Black Ven Press 2017

Illingworth, Sam, 'A Sonnet to Science', Manchester University Press 2019

Parkinson, Hannah Jane, 'From Keats to Merseybeat: A retreat into my favourite verse is a soul saver', The Guardian Online, 6 December 2019 
Corporate

Supporters:

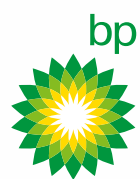

Convenors:

Alun Williams

Equinor

Andrew Barnett

Shell

Anna Matthews

BP

\section{Björn Seyfang}

Equinor

lan Saikia

ExxonMobil

Jo Garland

Cambridge

Carbonates

Paul Wright

National Museum of

Wales and Consultant

Trevor Burchette

Royal Holloway,

University of London

and CRG Ltd

Confirmed

Keynotes:

Mishrif Formation

reservoirs of

Rumaila Field

BP

Pre-salt reservoirs

of Lula Field

Petrobras

\section{Development and Production Geology of Carbonate Reservoirs 28-29 October 2020}

The Geological Society, Burlington House, Piccadilly, London

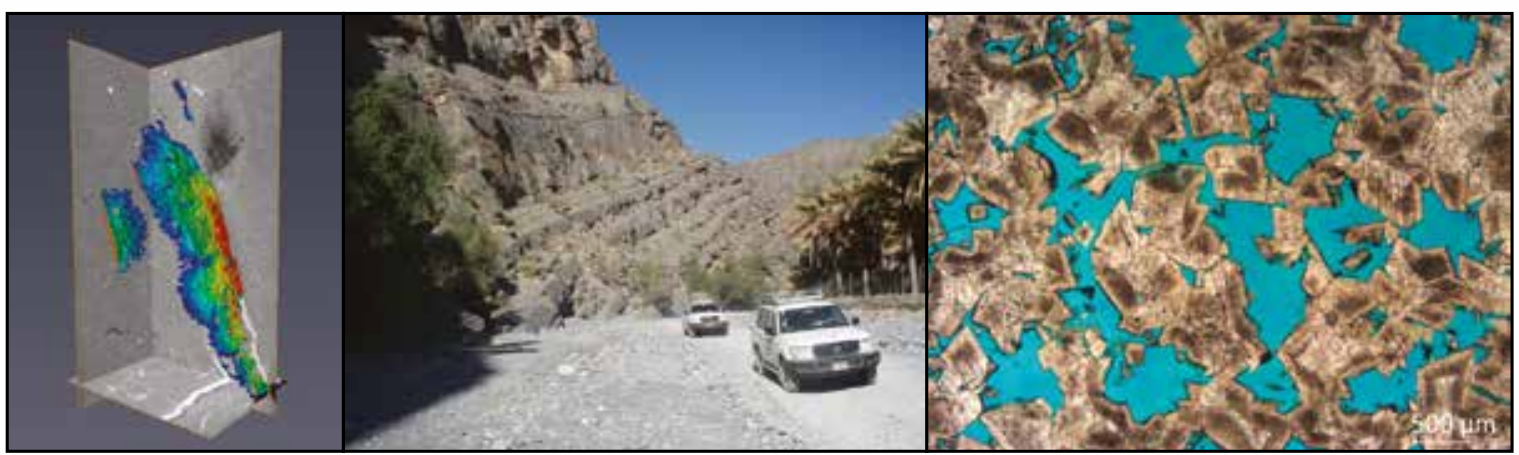

Carbonate reservoirs constitute some of the most important sources of global oil and gas production. They form the world's largest oil and gas accumulations, the world's highest-producing fields, and have some of the longest production histories. Significant new carbonate discoveries continue to be made, and carbonates are also a source of geothermal energy or may be utilised for gas storage.

Successful development of supergiant carbonate reservoirs can result in plateau production that may last for decades, giving high ultimate recovery factors. But, carbonate reservoirs can also be some of the most complex in terms of reservoir quality and heterogeneity. Many give disappointing ultimate recovery factors and some are deemed uncommercial with current technologies. Fundamental geological understanding, sufficient and appropriate geological and dynamic data, and the construction of effective models are the keys to optimising the exploitation of such reservoirs.

This conference will focus on how lessons learned from more than a century of discovery, appraisal and development of carbonate reservoirs may be applied to emerging discoveries. It will bring together the experiences of diverse operators with an objective of highlighting best practices for the geological characterization of carbonate reservoirs from appraisal to production.

Potential session themes:

- Excess permeability - blessing or curse?

- Pores vs stratigraphy - what controls dynamic reservoir behaviour?

- Reservoir analogues - how useful are they?

- Static modelling of carbonate reservoirs - how predictive can we be?

- Multiscale/multidisciplinary dynamic reservoir characterization - how can we integrate geology effectively?

- Improving recovery/revitalising old carbonate fields - adding value through geological understanding.

Planned field trips:

The Carboniferous platforms of Derbyshire, led by Pete Gutteridge, Cambridge Carbonates.

Zechstein carbonates of the north-east of England, led by Geospatial Research Ltd.

Call for Abstracts:

Please submit talk or poster abstract to sarah.woodcock@geolsoc.org.uk by 30 April 2020.

For further information please contact:

Sarah Woodcock, The Geological Society, Burlington House, Piccadilly, London W1J 0BG.

Tel: +44 (0)2074349944 


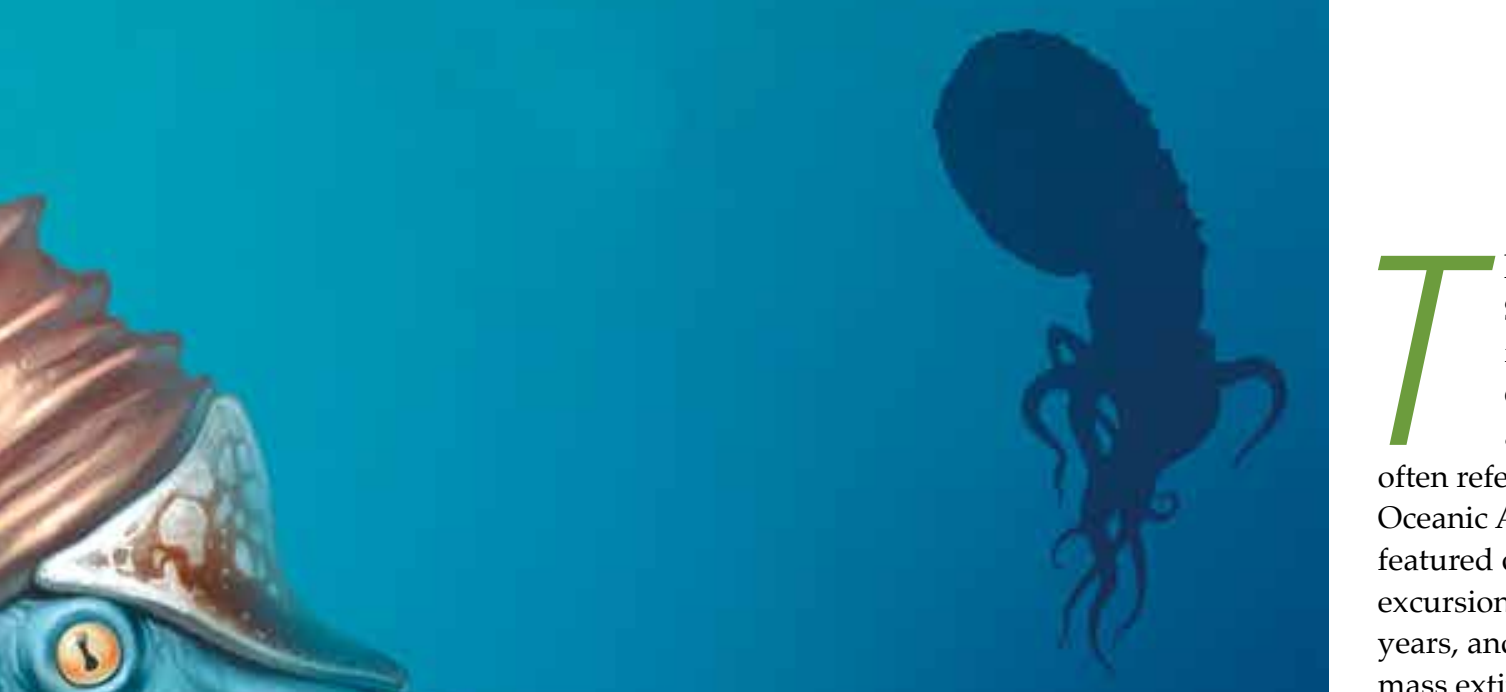

he early part of the Toarcian Stage of the Lower Jurassic is famous for one of the most extreme phases of oceanic anoxia in the geological record, often referred to as the TOAE (Toarcian Oceanic Anoxic Event). This phase featured one of the largest carbon isotope excursions (CIE) of the last 250 million years, and is claimed to coincide with a mass extinction.

Various causes for the TOAE have been proposed. One of the most popular is the release of isotopically light carbon from methane hydrates in marine sediments, linked to a phase of global warming as a result of the greenhouse climate effects of large scale volcanism - hence very much an Earth system crisis. The 'event' is also widely interpreted to have been characterised by a single phase of oceanic anoxia globally and hence the deposition of organic-rich mudrocks, some with a total organic carbon content (TOC) approaching $20 \%$ - indeed, some models actually require the development of the anoxia to be a single event.

Nevertheless, this synchronicity has been questioned by some authors who have presented evidence that it is either diachronous across Europe, between the southern Tethyan and northern Boreal areas, or even that there may be several events. Beyond Europe, even more correlation problems exist, so that even the global extent of a supposedly global event has been questioned.

\section{Jurassic chronologies}

Clearly, the application of a reliable high-resolution timescale would help resolve many of these problems. This should be available using ammonites, which form the framework for all Jurassic chronologies. Recent work on the basal Jurassic Hettangian Stage in south-west Britain, for instance, has demonstrated that the finest subdivisions of such a time scale, known as 'biohorizons', can have a duration of as little as 20,000 years, with the bases of such units effectively forming time planes for global correlations.

The reason this works is down 


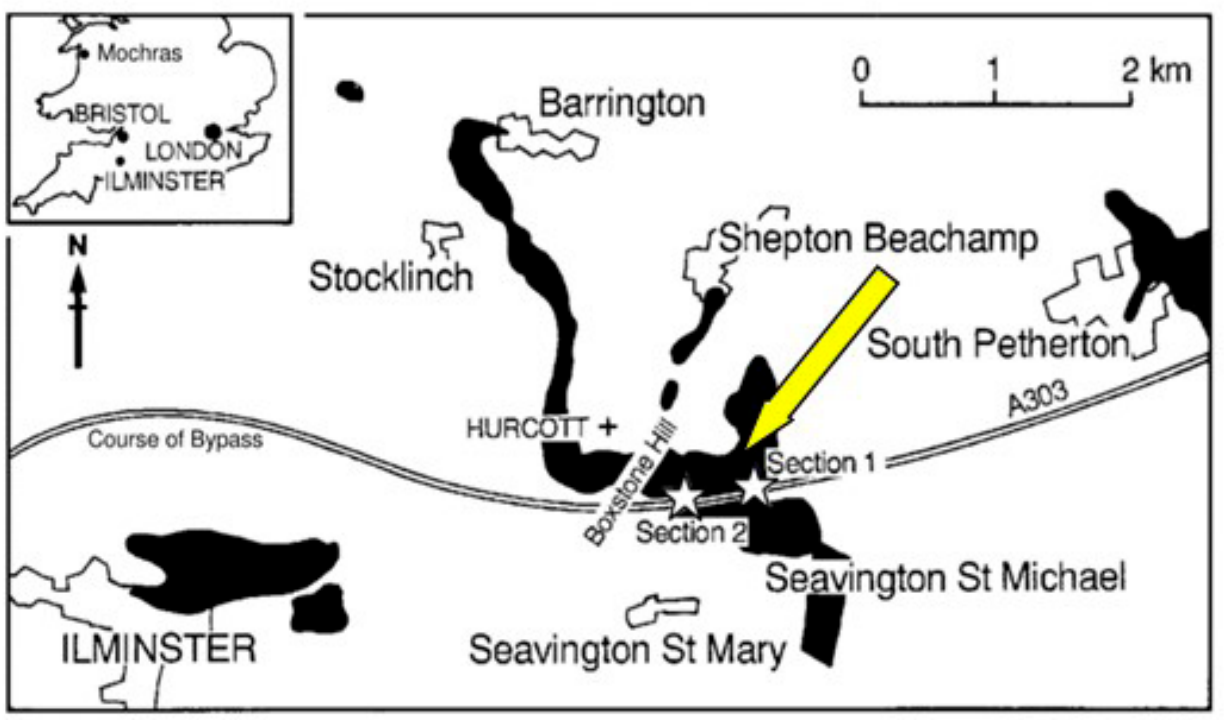

The outcrop of the 'Junction Bed' around IIminster in Somerset, in black, modified from Boomer et al. (2009). The stars mark the 1987 bypass sections and the arrow indicates the new site.

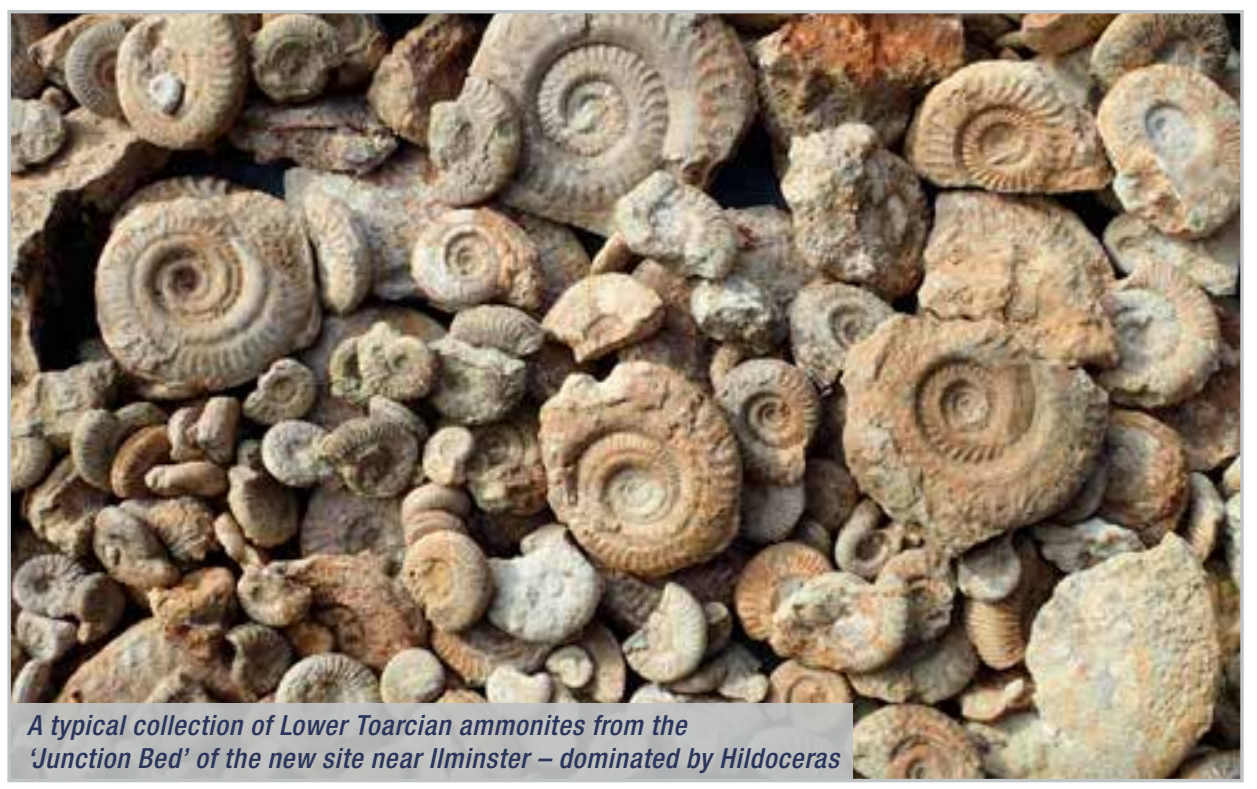

to the way in which ammonites behave A single individual of any planktonic or nektonic organism, such as an ammonite, could theoretically circumnavigate the globe in just 2.56 years - even passively, by simply drifting in ocean currents (assuming, of course, that no physical barriers to such movement existed, such as land areas). The appearance of different species of ammonites - and indeed any other fossil group with a similar life cycle - in different parts of the world would therefore be effectively instantaneous in the geological record. This provides a stratigraphical resolution simply not available with any other correlation tool - excepting very rare events, such as meteorite impacts or large-scale volcanic events.

Although ammonites travelled widely, they tended to 'live' in distinct

'bioprovinces' - areas with a characteristic suite of species, typically controlled by factors such as climate, water temperature and physical barriers which block migrations.

In the Toarcian, correlations between northern (i.e. Subboreal in a bioprovincial sense) and southern Submediterranean and Mediterranean (bio)province areas in Europe using ammonites remain poor due to a lack of understanding of 'southern' faunas by authors in northern areas and vice versa for authors in southern areas. This issue is particularly problematic for the region in which the TOAE has been most extensively studied, the North Yorkshire coast around Whitby.

The coast around Whitby lies within the Subboreal Province, with ammonite

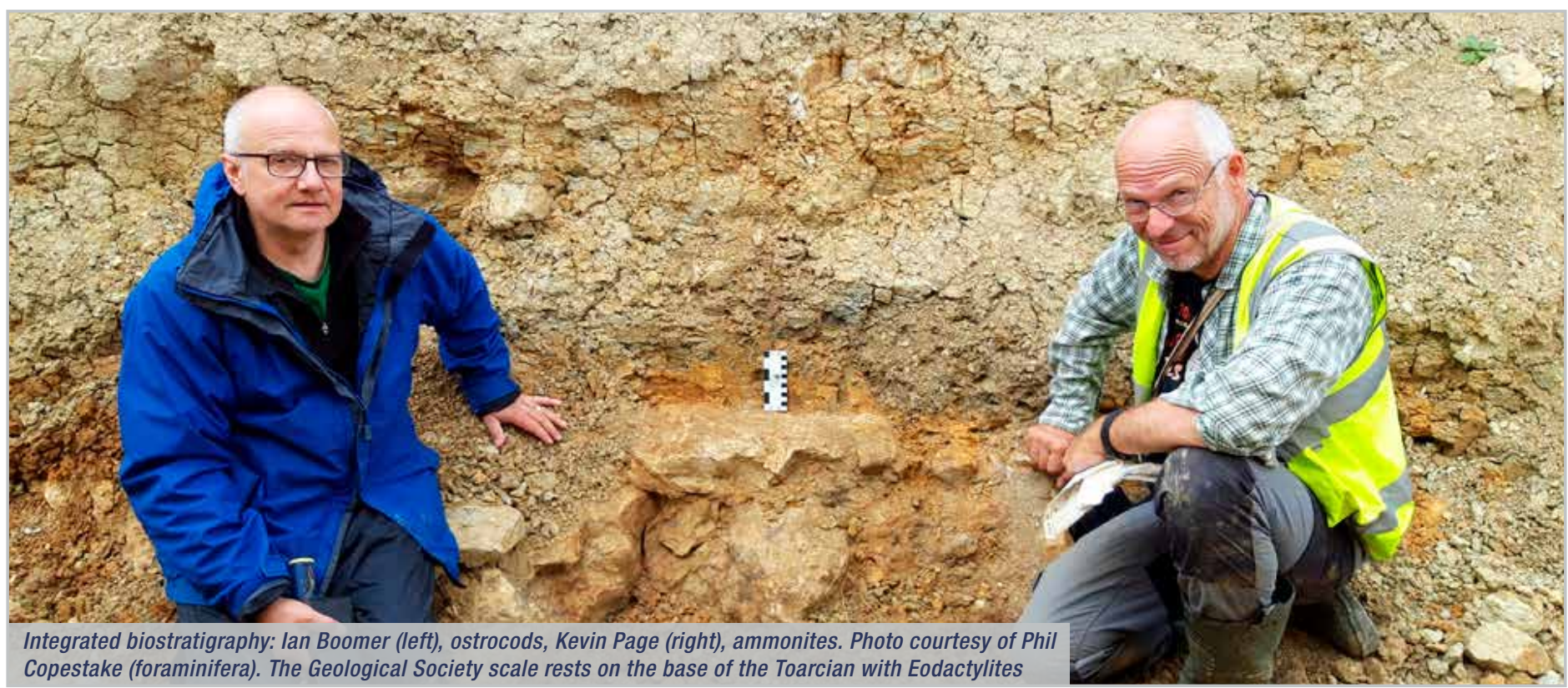


faunas dominated by coiled-rope-like dactylioceratid ammonites. But as the boundary with the Submediterranean Province, which characterises most of the rest of Europe, lies across central England, even correlations between northern and southern Britain have often lacked the necessary precision (Submediterranean faunas are typically dominated by flat-sided, wavy-ribbed and keeled harpoceratid and hildoceratid ammonites, which are usually quite rare in Yorkshire). This problem is compounded in much of the UK literature, which has inflicted an inappropriate Yorkshire-style Subboreal ammonite zonation on southern Britain. In fact, southern Britain shows much greater similarities with the

Submediterranean sequences of France, Spain and Portugal, including at both the historical type locality for the Toarcian at Thouars in western France, and its defining Global Stratotype Section and Point (GSSP) at Peniche in Portugal.

Improving these correlations has proven quite difficult. Although the Yorkshire coast sections remain spectacularly well-exposed in natural cliffs and foreshores - and comprehensively represented in museum collections, especially the Natural History Museum in London - equally useful exposures of Submediterranean sections have remained rare across much of Europe.

In Britain, sections of the Barrington Member of the Beacon Limestone Formation around Ilminster in Somerset - perhaps better known as the [Middle/ Upper Lias] 'Junction Bed' - have always had the potential to provide this new information. However, exposures of these ammonite-rich pelagic facies are even rarer, as the relatively soft limestone-marl alternations weather rapidly. But when exposures have been available, the results have often been spectacular.

\section{A brief history of the Ilminster "Junction Bed"}

The first systematic sampling of the unit was by a local vicar, Charles Moore, in the mid-19th century. Elected a Fellow of the Geological Society in 1854, Moore was an avid collector, whose finds formed the basis of what is now the 'Geological Museum' of the Bath Royal Literary and Scientific Institution. In the late 1840s

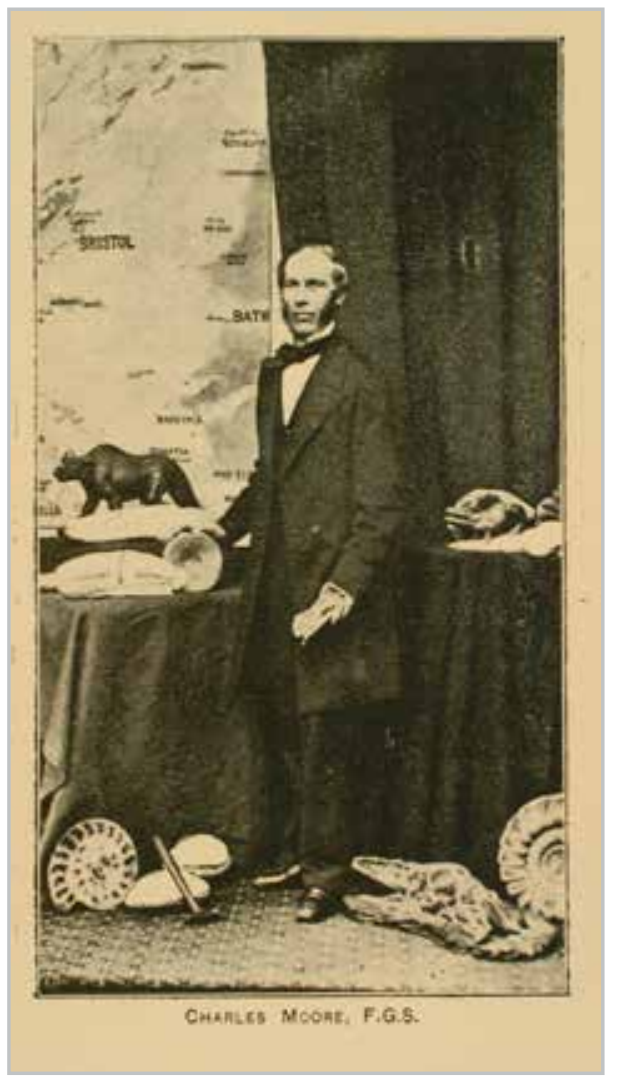

Charles Moore (1815-1881). Geological Society of London Archives

Moore discovered a rich and spectacularly well-preserved fish-reptileinsect fauna, within what is now known as the 'Strawberry Bank Lagerstätten'. He made an extensive collection from the horizon, even washing marl samples and describing a number of microfossil species - some of the first ever descriptions in the geological literature.

Further interest in the ammonite sequence were stimulated some decades later, when in the early 1920s the ammonite guru S. S. Buckman and others collected from a group of exposures around Barrington - which is close to Ilminster - the most famous of which was created as a reservoir was constructed. He described many new species from the area is his classic 'Type Ammonites' series. This work could not be reinvestigated, however, until the early 1970s, when a new reservoir section was sampled by Mike Howarth of the Natural History Museum in London. Not surprisingly, ammonites from the area were very well represented in his 1991-1992 Palaeontographical Society Monograph, where he announced that a remarkable 650 ammonite specimens had now been recorded from these sections.

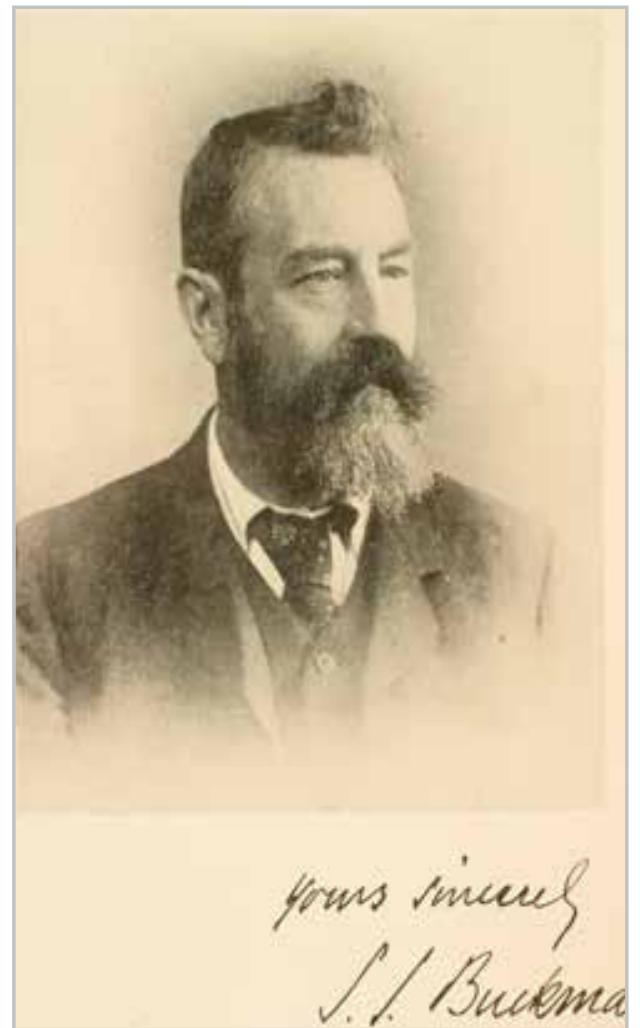

Sydney Savory Buckman (1860-1929), aged 56. Photograph by Maull \& Fox, published in 'Type Ammonites'. Geological Society of London Archives

Some 16 years later in 1987, another section appeared in roadworks when a new A303 trunk road was built across the area, by-passing Ilminster and other towns and villages. A group of intrepid PhD students from University College London jumped into a surprisingly sporty red hire car and headed for Somerset, to bag and tag mud for microfossil extraction. As a trainee ammonite worker, my role was to help place the sampling into the standard Jurassic stratigraphical framework of ammonite 'chronozones' (i.e. explicitly subdivisions of the global chronostratigraphical timescale of System and Stages).

What became apparent very quickly was that the Subboreal ammonite zonation developed in North Yorkshire, which had been applied up to that point to all UK Lower Toarcian sections, was simply not going to work. It would be necessary to adopt a Submediterranean scheme for the new section, as applied across France to Spain and beyond.

Nevertheless, the nature of the exposures on the construction site was very frustrating; short-lived pits and small sections would appear at 
- different times and in different places and hence no complete section of the Barrington Member was seen at one time. Most of the small sections did not last long enough to be systematically sampled for their ammonite fauna. Hence, even though the very well-exposed North Yorkshire sequence could still be restudied and a high-resolution sequence of ammonite biohorizons established, there was still not enough information from sequences in Somerset to do the same thing for Submediterranean areas.

Even re-examination of the only permanent exposure of the Barrington Member in the area, now protected as Hurcott Lane Section Site of Special Scientific Interest (SSSI), was very little help, as the high vertical faces along a dangerous country lane used as a 'rat run' by locals, are just not suitable or indeed safe-enough - for systematic sampling.

\section{A new hope}

In around 2010 a new section became available, thanks to work commencing on the construction of a potato processing plant close to both the former Ilminster bypass sections and Hurcott Lane SSSI.

There were difficulties with access initially - the site was subject to repeated raids by fossil collectors, many hoping to
66 SAMPLING BEGAN IN THE MISTS AND RAIN OF LATE OCTOBER 2018 - BUT BY THE BEGINNING OF 2020, SOME 3000+ AMMONITES LATER, NEW DISCOVERIES ARE STILL BEING MADE

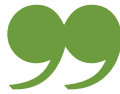

profit by selling the abundant ammonites. But by 2017 a local amateur, John Huxtable, had managed to negotiate access for scientific studies.

The access was granted initially for microfossil sampling by Ian Boomer (University of Birmingham) and Phil Copestake (Merlin Energy), and eventually for more general scientific sampling. The new sections revealed a complete and continuous sequence through $5 \mathrm{~m}$ of the Barrington Member, from the top of the underlying 'Marlstone Rock Bed' (Upper Pliensbachian) below, to very close to the base of the Yeovil Sands Formation (Upper Toarcian) above - the most complete section in the Member recorded anywhere since the 1920s.

The Barrington Member is remarkable for its richness in pelagic forms - particularly ammonites, but also belemnites - and the relative rarity of any bottom living macrofauna, including the bivalves and brachiopods which are usually so common in shallower water Jurassic sediments. An assumption that the environment was relatively deep is inescapable, reflecting the high sea-levels of the Lower Toarcian - although the microfauna of foraminifera and ostrocods is not so categorical.

As sampling for ammonites progressed, it soon became apparent that this was going to have to be archaeological in style due to richness of the faunas. A B\&Q putty knife became as useful as a conventional geological hammer, as the sequence was scraped and dug through, centimetre by centimetre. Such sampling would not have been possible without the support of the Geological Society through the award of the Gloyne Outdoor Geological Research fund to offset the costs, which was very gratefully received!

\section{$3000+$ ammonites later}

Sampling began in the mists and rain of late October 2018 - but by the beginning of 2020 , some $3000+$ ammonites later, new discoveries are still being made.

The core ammonite sequence is dominated by Submediterranean subfamilies Harpoceratinae and

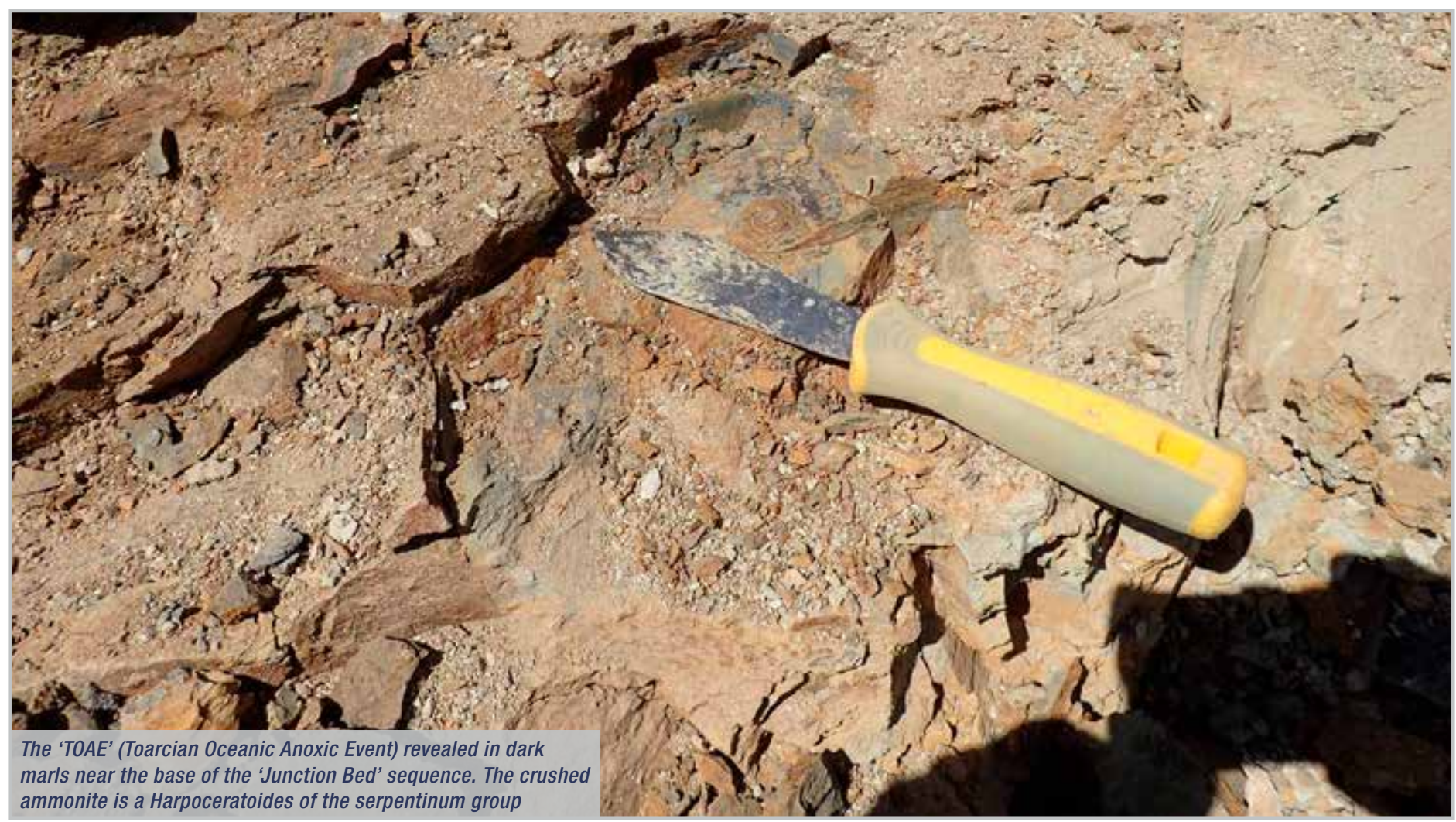


Hildoceratinae. The sequence of species for both subfamilies is the most complete known anywhere in Europe, with at least 10 successive species of Harpoceratoides-Harpoceras lineage and 13 of the Hildaites-Hildoceras group. Subboreal Dactylioceratidae are only common in the lower part of the sequence, with later genera such as Peronoceras and Catacoeloceras, which are abundant in North Yorkshire, being rather rare.

There have been two very notable new records. Firstly, Eodactylites at the base of the Toarcian, an indicator species of the base of the stage at its GSSP in Portugal, and often considered to be virtually absent in Britain. Secondly, the taxonomic usefulness of a previously rather 'suspect' genus has finally been clarified with the discovery of the type horizon of 'Rakusites pruddeni', named by the Swiss specialist Jean Guex in 1971 in honour of one of Somerset's most famous geological promoters, the late Hugh Prudden.

In all, over 55 successive levels have been sampled, some yielding over 100 ammonites. The richness of the faunas means that rarer forms have also been found. Many of these are also rare in Submediterranean sections across
Europe, and hence as 'exotics' may have limited correlation value across the Province.

They can be much more common, however, in true Mediterranean sequences bordering the Tethys Ocean further south, for instance in Italy and Morocco, so provide tantalising possibilities for correlations beyond Europe.

Other notable discoveries include new records for Britain of the elegant Tethyan Harpoceratinae, Polyplectus and Osperlioceras, the Ethiopean Bouleiceratid Frechiella, as well as Arctic Cleviceras, Ovaticeras and

Pseudolioceras (all Harpoceratinae - but also known, not surprisingly, from North Yorkshire). As processing and washing of the vast amount of material bagged and tagged to date proceeds, new records will undoubtedly appear.

\section{From 'relative' to 'real' time}

The next stage in the process will be to decide which of the new 55+ successive faunas can form the basis for a new sequence of ammonite-correlated high-resolution biohorizons for the Submediterranean Province. This will improve not only north-south Lower Toarcian correlations across Europe, but also correlations globally, as many of

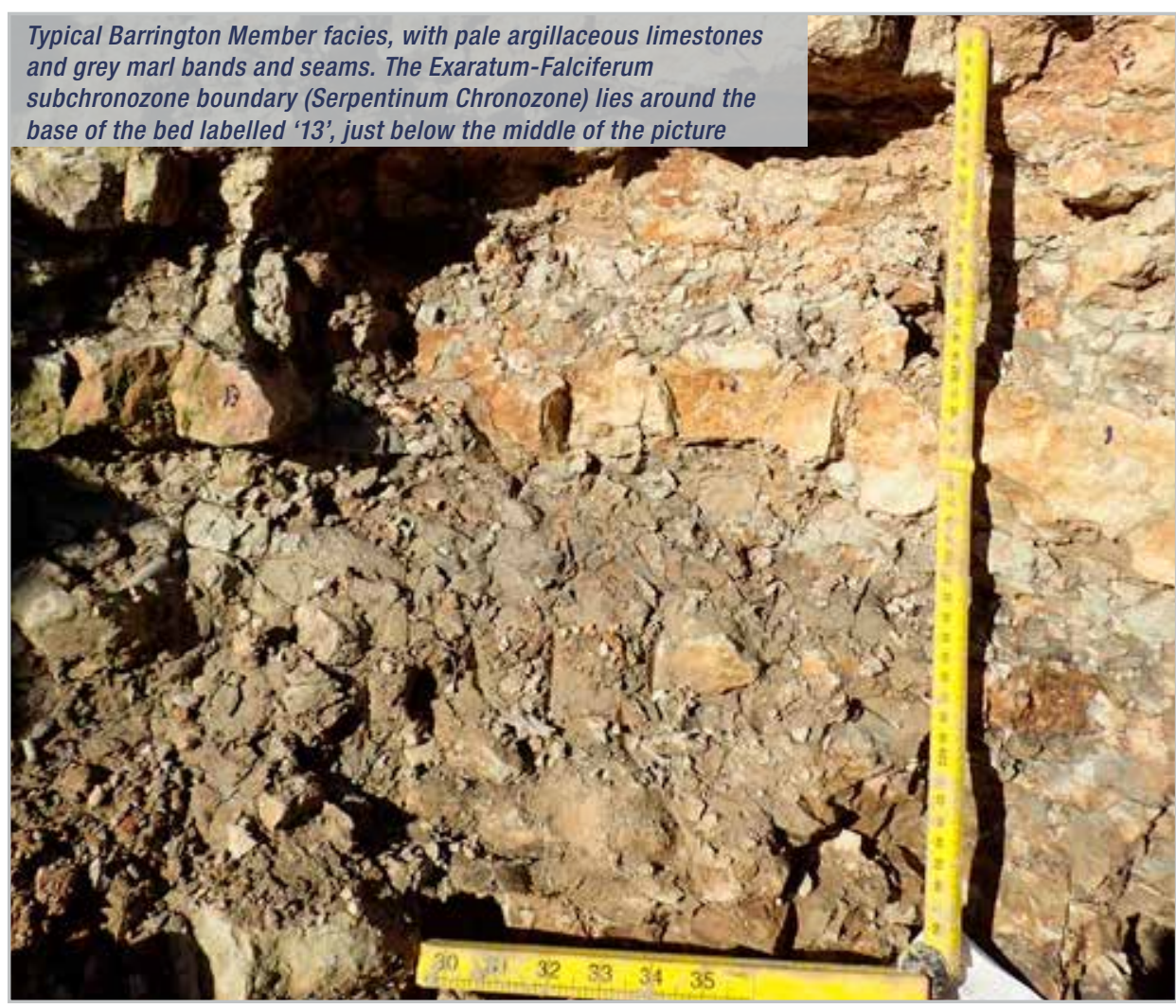

the genera present in Europe have counterparts elsewhere - and the 'exotics' mean that links at the species level can also help draw time-lines to much more distant regions.

In addition, this new and very high-resolution 'relative' timescale based on ammonites will soon become a 'real' timescale, as Milankovitch orbital cycle calibration of the Toarcian Stage is underway as part of the JET (Jurassic Earth Systems and Timescales) Project (http:/ / blogs. exeter.ac.uk/jet/). Just as the earlier Hettangian study confirmed the incredibly short duration of ammonite biohorizons and gave the Stage and its component ammonite chronozones and subchronozones a real timescale in 1000 s of years, such a timescale will soon be available for the Toarcian. With such a framework in place, it will finally be possible to make reliable statements about the chronology of Early Toarcian events, including the famed TOAE. Crucially, as this new chronology will be independent of any oceanic chemistry or ecological changes, it will, for the first time, provide a reliable test of synchronicity, duration and even rates of change through this remarkable time interval.

Kevin Page is Geoheritage and Geodiversity specialist and Honorary Senior Research Fellow at Camborne School of Mines, University of Exeter. He is Editor in Chief of the journal Geoheritage and was a 2019 recipient of the Geological Society's Gloyne Outdoor Geological Research Fund. Email: kevinnpage@gmail.com/K.Page@exeter.ac.uk

\footnotetext{
References

BOOMER, I., LORD, A.R., PAGE, K.N., BOWN, P.R., LOWRY, F.M.D. \& RIDING, J.B. 2009. The biostratigraphy of the Upper Pliensbachian-Toacian (Lower Jurassic) sequence at IIminster, Somerset. Journal of Micropalaeonotology 28: 67-85.

PAGE, K.N. 2017. From Oppel to Callomon (and beyond!): Building a high-resolution ammonite-based biochronology for the Jurassic System, Lethaia, DOI: 10.1111/let. 12209.

WEEDON, G. P., PAGE, K. N. and JENKYNS, H. C. 2018. Cyclostratigraphy, stratigraphic gaps and the duration of the Hettangian Stage (Jurassic): insights from the Blue Lias Formation of Southern Britain. Geological Magazine, DOI: https://doi.org/10.1017/S0016756818000808

WILLIAMS, M., BENTON, M.J., and ROSS, A. 2015. The Strawberry Bank Lagerstätte reveals insights into Early Jurassic life. Journal of the Geological Society, 172, 683692, https://doi.org/10.1144/jgs2014-144

A full list of references can be read online
} 
Quarterly Journal of

\section{Engineering Geology and Hydrogeology}

Current Thematic Collections

\section{Ground-related risk to transportation infrastructure}

This thematic collection is associated with a two-day conference on Ground-related Risk to Transportation Infrastructure. Transportation infrastructure is often referred to as the backbone of a modern economy, and as such it attracts considerable investment by many countries around the world.

To view the full collection visit:

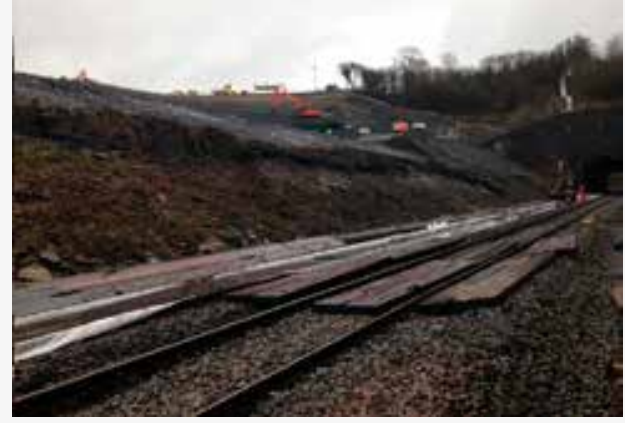
www.lyellcollection.org/cc/Ground-related-risk-to-transportation-infrastructure

\section{Keeping lessons alive in engineering geology}

The Malpasset Dam is a classic case-study in Engineering Geology, and was the subject of the honorary lecture given by Pierre Duffaut at the 2018 Annual Conference of the Engineering Group of the Geological Society. This thematic collection expores how we might keep such lessons alive.

To view the full collection visit: www.lyellcollection.org/cc/keeping-lessons-alive-in-engineering-geology

\section{Measurement and Monitoring}

This thematic collection of papers explores the range of methods and instrumentation now available to engineering geologists and hydrogeologists.

To view the full collection visit: www.lyellcollection.org/cc/measurement-and-monitoring

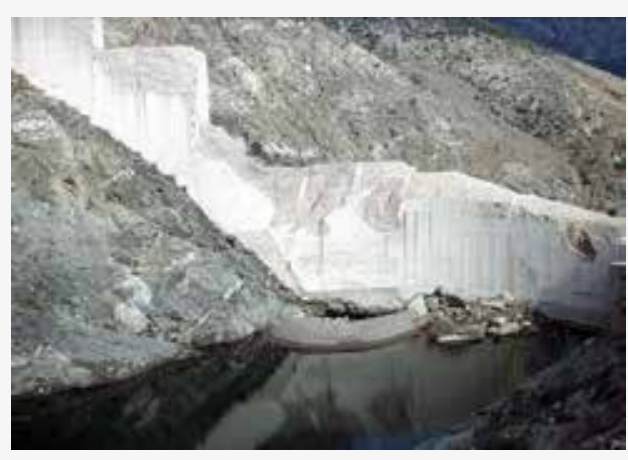

wWw.lyellcollection.org/cc/measurement-and-monitoring

\section{qjegh.lyellcollection.org}




\section{Geology from home}

\section{Many geologists are used to spending at least part of their working lives in the outdoors - but all that changed in March. Clive Mitchell from the British Geological Survey shares his experience of working from home during the current Coronavirus (COVID-19) outbreak}

M y current extended home working experience started on Wednesday 18th March 2020, along with a lot of my colleagues from the British Geological Survey (BGS). I work at the BGS headquarters in Keyworth, located just south of Nottingham, mostly on minerals related projects. My current work includes graphite resources in eastern Africa, Artisanal \& Smallscale Gold Mining (ASGM) in Kenya (both part of the BGS Official Development Assistance, ODA, research programme) and, closer to home, a new version of the BGS Mineral Planning Factsheet on Brick Clay.

My home is in Gedling to the east of Nottingham city centre. My daily commute has shrunken from 30 minutes down to 10 seconds (up the stairs and turn left into the spare room).

Instinct told me a couple of days before it happened that homeworking was imminent. I literally filled a box with rocks and stuck it in the boot of the car with my mini-microscope and plenty of minerals books. I'm glad I did - later the same day the home working request was announced nationally. I went into the office the next morning to gather my essentials together - I have a laptop with a docking station that allows me to connect a monitor and keyboard. I'm so glad I bought this home with me!

I set up my new office, in what I'm calling the Gedling branch of the BGS, on the first morning of home working and I pretty much hit the ground running. I think this was mainly fuelled by an initial burst of energy. ('Even more energy?!' my BGS colleagues will think!) I have calmed down a little since then.

After day six of working from home, here are some of my tips for home working that might help if like me, you are adapting to new challenges and rapid changes:

\section{Try to keep work \& home apart}

I've been sticking to my usual office hours, but with a much longer lunch break. I'm lucky to have a spare room to work in, which means I can close the door on work until the next day. I usually put on a work shirt too - old school, maybe, but it makes me feel as though l'm at work. And when I return (get to the bottom of the stairs) I always say 'I'm home!' It's the little things like this that I feel will keep me sane.

\section{Stay in touch}

It's tempting to go into work isolation mode but l've found that my day improves when I'm in contact with people. I appreciate it when people share their experience of the current situation, no matter how fleeting. The BGS has been using Zoom for video meetings. For example, this morning the BGS minerals team had a virtual coffee time using Zoom and it lifted my spirits immeasurably.

Don't overdo it! People often comment on how much extra they get done when they work at home - fewer interruptions mean more focus. I would normally only work from home on very rare occasions, typically when I need to focus on writing. This is fine for a day or so. However, as it's a more concentrated form of working I figure that I need to pace myself for the long haul.

\section{Get some exercise}

I do exercise regularly. However I think the point is that it is not just the physical exertion that is important. It's the change of scenery, the fresh air and sunshine too. My colleagues at BGS in Keyworth will smile at this - sunshine can be rare in the East Midlands! Each day at lunchtime I take a long walk (before I get collared for jobs around the house!) and l've really noticed a difference afterwards. As geologists, the outside is for many of us our natural habitat - if you're lucky you might see a few rocks on the way, too.

I hope that you are faring well and that if you are working from home it's a good experience. Hopefully we can all take some positives from this experience back to the workplace. Connecting more with people is one lesson l've already learnt.

Clive Mitchell is Industrial Minerals Geologist at the British Geological Survey. Follow Clive on Twitter via @CliveBGS to keep track of how he is getting on working from home.
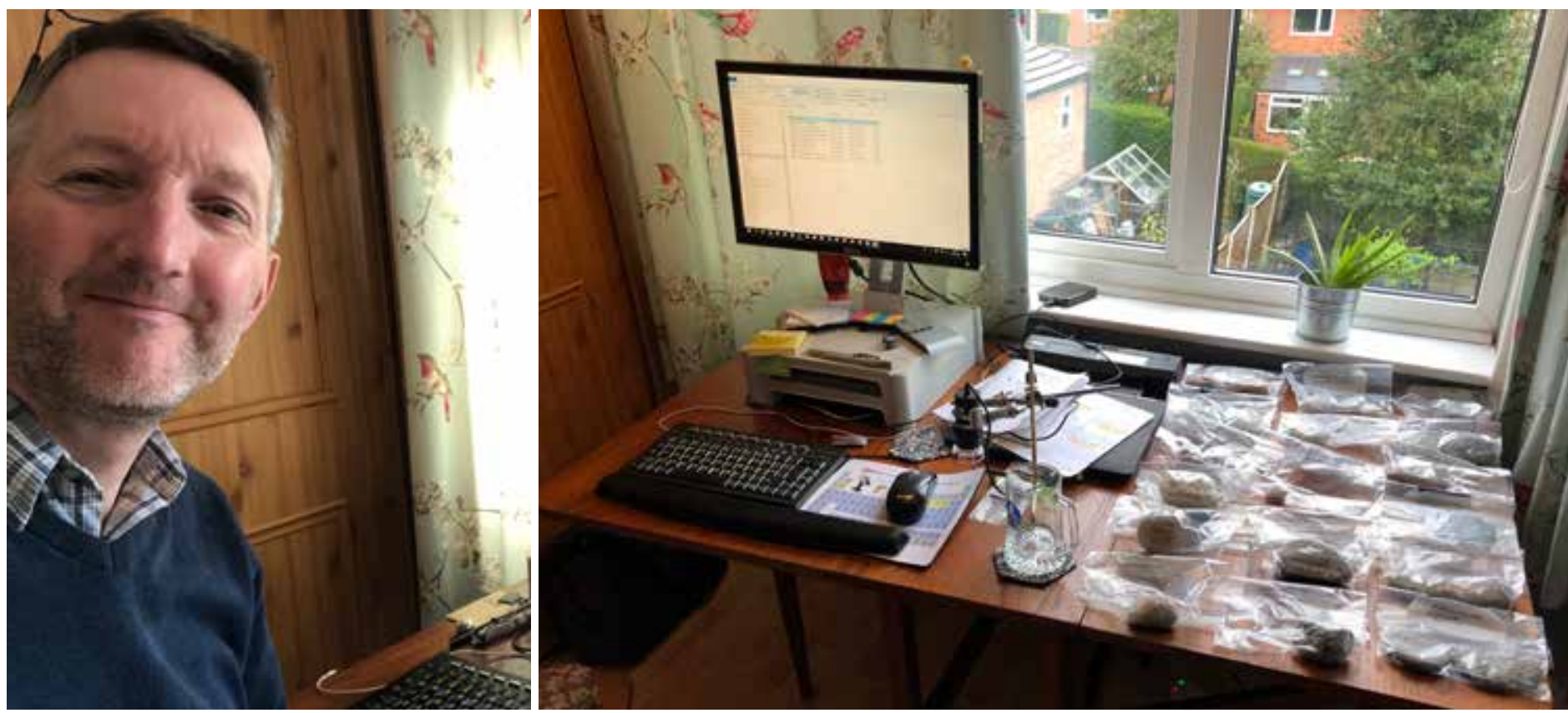


\section{Extinction: A Very Short Introduction}

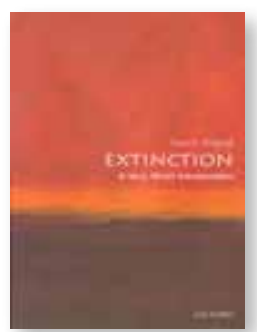

Hardly a week goes by without a reminder on the news of yet another hapless species on the brink. Occasionally, as with the Northern White Rhino, it is more than just a close call.

But surprisingly, the idea of extinction is something relatively new that developed alongside evolutionary theory two centuries ago. And much like its sibling in science, what seems straightforward in concept is in reality complex and fertile ground for rigorous debate.

Wignall introduces us to the points of debate and outlines the key areas of the science. As with any work related to the geological record, gaps and inconsistencies lead to rival ideas. The demise of the dinosaurs is a good example of this. The Alavarez meteorite hypothesis introduced in 1980 did not gain full acceptance for several decades until further more detailed work confirmed it. Now the K-T boundary site in Gubbio, Italy is something of a Mecca for palaeontologists.

The issues around measuring extinction are mainly statistical and Wignall covers these brilliantly with clear diagrams and illustrations. This does not detract from the overall feeling of shame at the scale of destruction that humanity has wrought upon the organisms we share our planet with. The only good news is that when compared to the greatest extinctions our planet has ever seen, we still fall somewhat short of the mark (maybe). With enough time and money perhaps the efforts of conservation and climate change mitigation can prevent us claiming the title of largest mass extinction from the Permo-Triassic event.

But in case conservation isn't your thing and you ever feel the need to wipe out life on our humble little planet, the aptly titled chapter "How to kill nearly everything" should prove a handy guide. From meteorites to climate change, the potential devices of mass extinction are numerous.

They can also hide themselves surprisingly well in the geological record. Even as recently as the Pleistocene, large animals have been disappearing en masse without an obvious culprit. The case for blaming humans is examined in the final chapter, along with our lack of close relatives.

Wignall has made this Very Short Introduction an accessible and fascinating read, with well selected figures and chapter topics. Those familiar with the topic of extinction are bound to discover something new here and those less well versed will find themselves questioning their very understanding of the word.

\section{Reviewed by Jonathan Scafidi}

EXTINCTION: A VERY SHORT INTRODUCTION by PAUL B. WIGNALL, 2019. Published by Oxford University Press 124pp (pbk) ISBN: 97801898072853 List Price: £8.99 W: https://global.oup.com

\section{The Moon: A History for the Future}

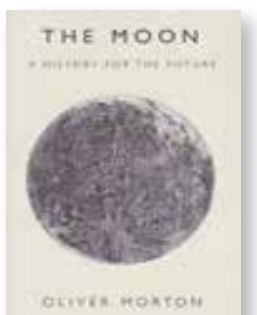

The Moon: A History for the Future breaks broadly into three parts: the cultural history of the moon and the various myths around its creation throughout human

history; historical studies of the moon from the earliest scientific studies through Galileo and even Verne up to Apollo; and finally the more recent scientific studies and engineering approaches aimed at taking humanity back to the lunar surface and beyond.

As readers of Morton's other books on Mars and environmental issues will know, he is a clear and compelling author who has the ability to weave a narrative through what might otherwise seem completely unrelated topics.

However, despite his skills there are places throughout where the book's different topics are unhappy bedfellows. The history can at times be not quite complete enough and in a similar way the science can be touched on a little too briefly for anyone wanting to dig a little deeper.

If this book is approached as a useful primer on the moon, as perhaps the author intended, it will please the reader more. Sources and further reading are provided that allow the interested reader to jump off to whichever area most interests them.

Morton starts with ancient myths of the formation of the moon and progresses through its place in Victorian fiction, eventually bringing us through the Apollo age and to the present.

It's here, in this reviewer's opinion, that Fellows not working in the field of planetary sciences will find the most material of interest. Coverage of Goldblatt et al's 2010 work on the Hadean and Chaotian eras was particularly interesting, and there are a number of similar instances where the science is well placed in a cultural and historical context.

The section covering the stories of Earth's billionaire elite competing for different visions of space exploration is also well written, but suffers a little from not bringing along new information for the reader who has kept relatively abreast of the periodic news coverage on the topic.

In summary, a good book for anyone looking for a broad and quick primer on our nearest celestial neighbour but who doesn't want too much detail, or for anyone looking for a subjective list of highlights of recent lunar studies and the current drive to return humans to the lunar surface.

\section{Reviewed by Les Hopper}

THE MOON: A HISTORY FOR THE FUTURE

by OLIVER MORTON, 2019. Published by: Economist Books, 352pp (hbk) ISBN: 9781788162548

List Price: £20.00 W: https://www.profilebooks.com/

\section{Tales from the Himalaya: Religion, Science, Politics, Society}

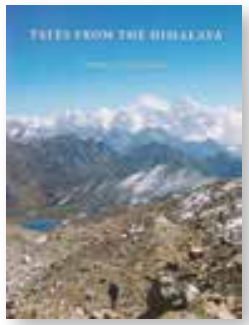

This excellent book is about people and peoples in and around the Himalaya. Dealing largely with Tibet and Nepal, it includes Bhutan, Sikkim, etc, as well. It is actually four books in one, covering the sub-title's topics, although with unequal weight and dealing in most detail with the people(s) involved. The treatment of the major topics in the book is such that all of it is fascinating; in addition to which it contains a large number of pictures. All of the latter are well reproduced, and 
almost all are good quality, many presented as impressive double-page spreads.

The first section - religion - is mainly about Buddhism but includes intriguing information about pre-Buddhist beliefs in the region, and particularly Tibet. The importance of religion in Tibet, etc, is probably symbolic of the peoples, which makes the section a valuable opener for the work. Apart from the region's religious history, which is as complex and full of intrigue as one might expect, the section deals with the variations in political and religious control over the last 1,500 years or so, and contains a brief and clear-cut outline of the differences between the two principal Buddhist doctrines.

"The plates must speak" is about the geology of the region and, even more, those - especially from the Geological Survey of India but there were many others - who studied and clarified it. Like the geology of the region, the story is complex but interesting. As a summary that highlights the flow of changes in understanding and how they arose, the section is interesting and worth reading. It is not, however, a scientific treatise on current understanding and/or knowledge of Himalayan geology and structure, and the author does not pretend that it is.

"Controlling the Margins" is a discourse on the Himalayan region's history since about the mid-eighteenth century, and some of the extraordinary people who shaped it. Starting in Jammu and Kashmir, with the murder of Nadir Shah and related re-looting of the Koh-i-Nor diamond, it deals with the area's very convoluted politics, ending with some of the impacts of the later twentieth century Chinese-Tibetan conundrum. This leads nicely into the book's final section - covering Nepal's recent history, the Ghurkas, this century's major Nepali earthquakes, and the diaspora providing labour in the Middle East (and funds back in Nepal). This book contains much interesting information on both the Himalaya and its peoples, and is highly recommended

\section{Reviewed by Jeremy Joseph}

TALES FROM THE HIMALAYA - RELIGION, SCIENCE, POLITICS, SOCIETY

by Henry Edmundson, 2019. Published by: Vajra Books, Kathmandu, Nepal. ISBN: 978-9937-9330-3-

2. 423 pp (pbk)

List Price: \$52. W: www.vajrabooks.com.np

\section{Deep-Sea Mining: Resource Potential, Technical and Environmental Considerations}

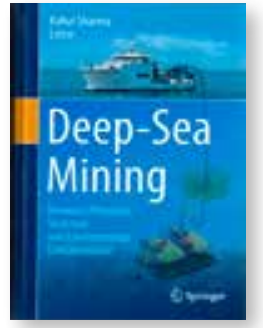

The title of this book is something of a

misnomer; if and when deep-sea mining might ever be undertaken are still open questions. Notwithstanding, the book gives a useful snapshot of the current state of play and should be of interest to individuals and organisations involved.

Part one deals with the nature, distribution and resource potential of deep-sea minerals, and will be the section of most interest to geologists. An authoritative overview of manganese nodules is patchy in detail. For example, it is mentioned that whether or not nodules become 'economically interesting' depends on their relationship to the calcium carbonate compensation depth, water depth, surface bioproductivity, sedimentation rate, sediment type, benthic activity, near bottom currents and local microtopography. Well, yes, but it would have been useful to discuss how these processes work and interact.

An overview of Co-rich ferromanganese crust deposits is dealt with well by an acknowledged authority in the field. One aspect that could have been covered more fully is the regional compositional variability of the deposits - surely of interest to future deep-sea miners. A concise and authoritative account of work on massive sulphides could have gone into more detail on exploration, whilst a chapter on phosphorites reviews mostly old material - probably because not much recent work has been done in comparison with other marine minerals.

The second part deals with mining concepts, beginning with geotechnical considerations that might be taken into account in the design of deep-sea mining systems. Unfortunately, a chapter reviewing historical developments and various proposed mining systems repeats the erroneous statement that the first nodules to be recovered from the Indian
Ocean were by the R V Gaveshani in 1981 - they were actually first recovered much earlier than this.

Part three deals mainly with metallurgical processing of nodules. Some economic models for nodule utilization put processing at more than $50 \%$ of the total cost, so advances in this field could substantially affect the overall profitability of deep-sea mining.

Part four deals with environmental aspects of deep-sea mining - possibly the most contentious aspect of the subject. Of the most potentially serious environmental impacts of deep-sea mining are the destruction of marine organisms and the development of sediment plumes. The section reviews some Japanese work in this field, as well as taxonomic problems, the background to and development of an environmental management plan for deep-sea mining, international regulating agencies and the crafting of seabed mining ecosystem based management. This comprises only a limited number of aspects of what is a very complex subject, which really needs a book of its own.

\section{Reviewed by David Cronan}

DEEP-SEA MINING: RESOURCE POTENTIAL, TECHNIGAL AND ENVIRONMENTAL CONSIDERATIONS

by Rahul Sharma (ed) 2017. Published by: Springer International 535pp (hbk) ISBN: 9783319525563

List Price: £159.99. W: www.springer.com

\section{Cowen's History of Life: Sixth Edition}

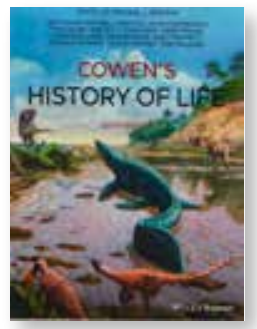

Designed primarily as a textbook for undergraduate students, this is an invaluable tome for anyone interested in the history of life on Earth. It is written in an engaging way and allows the reader the opportunity to study the huge breadth of the subject in a concise way, highlighting key events that have allowed us to develop our understanding of the topic.

This is a multi-authored volume written by experts in their field under the expert leadership of Michael Benton. It is 
excellently set out with clear chapters dealing with the information in a systematic and thorough manner. It can be dipped into or studied in depth to allow the reader to develop a clear understanding of the evolution of life on Earth. There are excellent introductions to each of the chapters, which explain the significance of the information that follows.

Key references are included, suggestions for further reading, as well as questions for further discussion. These make the title an excellent resource for students and one that should be available to all students starting out on the study of palaeontology. The diagrams are excellent and illustrate and enhance the material included and the book clearly achieves its stated purpose of being accessible to undergraduates with no academic background in the subject.

The volume takes us to the very edge of current knowledge (when the book was published) and not only covers the biological evolution of organisms, but also discusses their adaptations, as well as the ecology and environments in which they lived. It is quite simply a stunning volume and well worth the money.

It has not shied away from admitting where we still need to develop our understanding - something invaluable in a text such as this. I shall be using it to inform my teaching and would thoroughly recommend it for anyone with even the slightest interest in the subject matter. There is an excellent glossary which allows the reader to understand the myriad of terms introduced into the text.

As well as being invaluable to undergraduates this book would not be out of place for A-level students of geology; with its associated dedicated website there is much here to allow further investigation for the interested student. This book should be available on the shelf of all university geology departments and I would suggest it is essential for all teachers of A-level geology as well!

\section{Reviewed by Gordon Neighbour}

COWEN'S HISTORY OF LIFE - SIXTH EDITION by Michael J. Benton (editor), 2019. Published by: Wiley Blackwell. 400pp (pbk). ISBN: 978-1-11948221-5

List price: $£ 49.99$ (e-Book), £55 (pbk)

W: www.wiley.com

\section{Delving along the Derwent: A history of $\mathbf{2 0 0}$ quarries and the people who worked them}

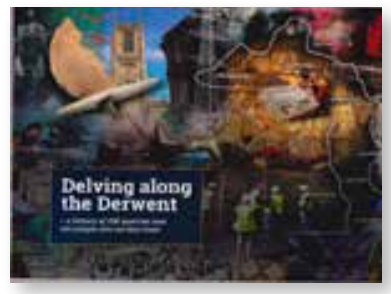

Delving along the Derwent is a collection of geological and historical

information connected to quarrying and related industries that grew up along the River Derwent between Derby and Matlock. This area is now recognised as a World Heritage Site for the role it played in the industrial revolution and the birth of the factory system, made possible by its geology. This provided a ready availability of limestone, sandstone, minerals and coal, coupled with the power of the River Derwent.

The area has also been an important source of building stone, grindstones for mills, agricultural lime, pottery clay and lead ore since pre-Roman times, but the bulk of the information is about the post-1700 industrial history. The network of canals and railways that grew up alongside these industries to transport goods and raw materials are also included, as well as geological sites.

An outline of the Carboniferous geological history explains why there is such a concentration of strategic raw materials in this area. The book is split into two sections; the Sandstone Zone in the south and east of the area dominated by the Millstone Grit with parts of the Westphalian and Triassic, and the Limestone Zone in the north of the area in which the Carboniferous Limestone Grit crops out.

In each area, there is a comprehensive account of all the quarries and works, covering the methods of extraction, treatment, transport, uses and markets for each rock type in each area. There are also numerous historical maps, plans and photographs of many quarries while they were still in operation. There is also a wealth of information about the people who owned and worked the quarries, the history of ownership and their disputes.

This is a book to be dipped into and will make an essential companion for a geologically inclined visitor to the Peak District. The few downsides include the cross referencing which could have done with a bit more editing and although there isn't a reference list, there is a section detailing all the sources of information.

On the other hand, you get the impression that every possible fact about every possible geologically relevant industrial site has been relentlessly tracked down and extracted from historical records as efficiently as the sandstone and limestone have been extracted from the various quarries. If this isn't a comprehensive account of the industrial history of this part of Derbyshire, I don't know what is.

\section{Reviewed by Peter Gutteridge}

DELVING ALONG THE DERWENT: A HISTORY OF 200 QUARRIES AND THE PEOPLE WHO WORKED THEM

by lan Thomas et al., 2019. Published by: Gomer Press, 191pp (pbk). Further information: ianathomas2@gmail.com

\section{BOOKS FOR REVIEW}

Please note, there may be a delay in supplying review copies whilst our offices are closed due to COVID-19. Please contact sarah.day@geolsoc.org.uk if you would like to supply a review. See a full, up-to-date list at www.geolsoc.org.uk/reviews

NEW! Applied Concepts in Fractured Reservoirs, by John C. Lorenz and Scott P. Cooper, Wiley Blackwell 2020, 211pp, hbk.

- Paleozoic Plays of NW Europe by A.A. Monaghan et al. (eds), Geological Society of London SP 471 2019, 398pp, hbk.

- Development of Volcanic Gas Reservoirs: The Theory, Key Technologies and Practice of Hydrocarbon Development by Qiquan Ran, Dong Ren \& Yongjun Wang, Elsevier (Petroleum Industry Press, Gulf Professional Publishing) 2019, 1066pp, pbk.

- Plant Flow Measurement and Control Handbook: Fluid, Solid, Slurry and Multiphase Flow, by Swapan Basu, Elsevier Academic Press 2018, 1288pp, hbk.

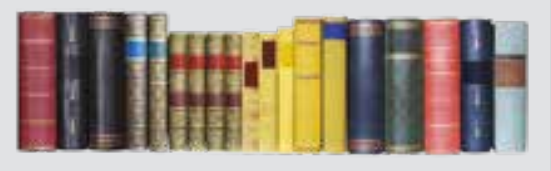




\section{ALL BY MY SHELF}

Dear Editor, In response to your request for accounts of working from home (via twitter, @geoscientistmag) - as an engineering geologist in the UK construction and transport industries, much of my work is continuing as usual, albeit from home. It's led me to think about how our working practices might be impacted. For some of my colleagues, particularly those with young children, it's very difficult but personally l've found the whole experience energising. I love working from home. I've found motivation and a new lease of life I didn't realise I was missing.

It's had such a positive impact on my health and happiness, I'm considering making it a permanent arrangement in future. I suspect I won't be the only one, and that employers will find many of us want to be more flexible in our working locations. It will be interesting to see, should this play out, what impact this has on institutional memory and skills transfer.

As what l'm still thinking of as the 'normal' course of things, a days' work involves passing colleagues in the kitchen and sharing technical anecdotes and techniques, hovering over each others' desks and gossiping about the industry and the minutia of soil mechanics. It's how we learn, and probably the most important way we develop a breadth of skill appreciation, knowledge and eventual expertise.

While it's possible for us to all work in separate locations, and while intentional training is also important, we do lose the desultory collaboration that often - in our office at least - results in innovation and a mingling of different points of view and expertise. I hope the circumstances that mean we're all sheltering in place are short term, but it seems our working practices will be impacted in ways we haven't yet worked out. I plan to observe carefully and continue to navigate collaboration as best we can hopefully with better long term results for all of us.

Perhaps the magazine should run a regular feature in which readers share photographs and anecdotes of favourite rocks in their home collections. 'All By My Shelf'?

I hope everyone's staying well.

\section{ALEX BOOER (FGS)}

\section{ALL BY MY SHELF - REPLY}

Thank you to everyone who's been in touch with us via social media and email to let us know how you're getting on. We very much hope the current situation won't last long enough to warrant a regular feature - but if you have a home rock collection you'd like to share with us on twitter (@geoscientistmag) using the hashtag \#AllByMyShelf, we'd love to see them. If you want to share your experiences of home working, home schooling, and how you're dealing with the current situation, you can tweet us or write to me via the usual address (sarah.day@geolsoc.org.uk). Thanks Alex for the idea, and we sincerely hope all our readers are staying safe and well.

\section{SARAH DAY (EDITOR, GEOSCIENTIST MAGAZINE)}

\section{ENGAGE WHERE PEOPLE GO!}

Dear Editor, I read with great interest the soapbox article by Catherine Kenny in the April issue of Geoscientist (Engage! Geoscientist 30 (3), 9 , 2020). As a geologist, I am a passionate and enthusiastic advocate of engaging with all ages. I think Catherine is right when she says that reaching the younger generation is the real issue. Igniting the spark of geological curiosity is a wonder to behold - I know from personal experience of showing primary school kids how to use a simple hand lens and the sudden "Oooooo" moment when it all comes into focus.

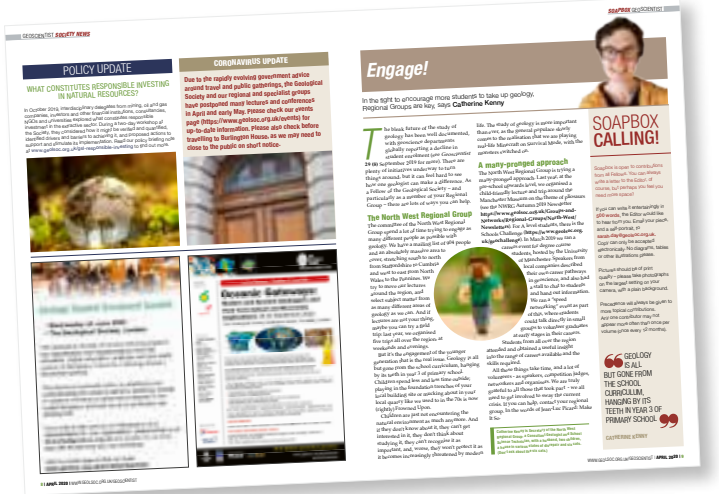

However, lectures, field trips, museum tours and careers events (which I hasten to add are fantastic) run the risk of only engaging with a self-selecting audience. To engage more widely, I think we need to adopt the commercial marketing strategy to 'go where people go'.

A couple of examples: Catherine mentioned Minecraft. At the peak of the video game's popularity the British Geological Survey innocently released the geology of Great Britain for Minecraft - the response was by far and away one of the biggest the BGS has ever had to a release of anything geological! When the augmented reality Pokémon-Go craze was at its height, the BGS discovered several Pokémon on the Geological Walk at its site in Keyworth - this led to a large increase in visitors who learnt a little geology on the way around!

A great starting point would be to collaborate with the fantastic Education team at the Geological Society led by Judi Lakin. So to paraphrase another Star Trek Captain, James Tiberius Kirk, we need to: Boldly go where no geologist has gone before. 


\section{On the moors with Ted Hughes and Ovid}

\section{Mike Stephenson recounts a recent geology walk which revealed links between poetry and geology}

1 ou could say that geology is the study of transformation - how physics, chemistry and biology wreak their changes on the earth. Earth's rocks contain records of those transformations; an entire class of rocks ('metamorphic') is named after change of form. Observing the characteristics of change helps geologists reconstruct the processes that cause it, and recognise the states of change along the way. We even use a term co-opted from literature - 'palimpsest' - that describes structures in rocks that give clues to their ancient origin where the superimposed changes have not removed everything.

A recent walk on the moors with the Yorkshire Geological Society to celebrate the geology and poetry of Ted Hughes made me think of the similar ways that geologists and poets explain and react to the landscape and processes of change around them.

\section{Metamorphosis}

The walk started at Widdop Reservoir above Hebden Bridge and scaled the moors over wild Cludders Rocks down to Dicken Rocks. I read some of the best poems from Hughes' collection The Remains of Elmet, and also introduced the group to Hughes' translation of Ovid's Metamorphoses. Reading Ovid's tale of Niobe, a woman so struck by grief that she turned to stone, while standing underneath the overhanging human-like masses of Dicken Rocks seemed to bring the 2000

year-old poetry to life. I was struck by how transformation is central to the work of both the poets and geologists.

Three of Hughes' poems, Wild Rock, Hillstone Was Content and Moors, were popular with the Yorkshire Geological Society walkers perhaps because they too explored the idea of change. The first two were inspired by pictures by the photographer Fay Godwin of Cludders Rocks and scenes of stone buildings on Calder valley hillsides. Cludders Rocks is a scarp of lower Kinderscout Grit above a tumble of boulders overlooking Widdop reservoir. The two poems explore a theme of Hughes' - that of stone taken from its natural hill habitat, and cut and fashioned for building. He speaks of the stone being 'conscripted' for the building of houses and mills in the industrial revolution, while the people of the valleys dream of industry, or organised work:

converting their ideas to woollen weave

In Hill-stone Was Content Hughes is fascinated by the transformation of stone from the stuff of the hillsides, the load-bearing layers of the landscape, to a captured and controlled existence in the walls of factories and houses. He sees this cut stone itself undergoing change - being worn down by the persistent rain, but trying to resist:

Against the guerrilla patience Of the soft hill water

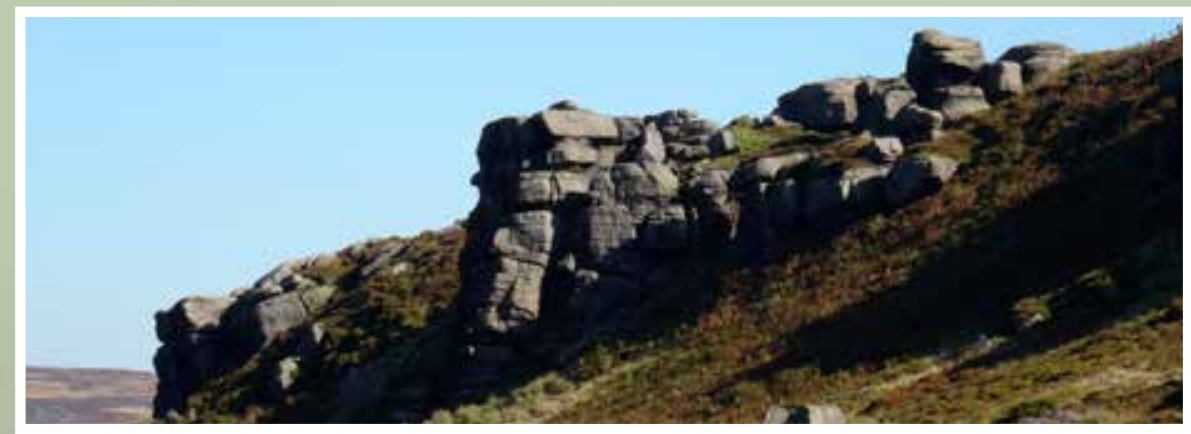

Cludders Rocks, made up of the lower Kinderscout Grit, once cut and carted to build the houses, factories and mills of the industrial revolution of the Calder Valley

\section{Topheavy Kings and Queens} It was at nearby Dicken Rocks, over the hill from Cludders Rocks, where Hughes' translation of Ovid's ancient verse and his own poem Moors seemed to speak to the group most vividly. Where Cludders Rocks are a disorganised tumble, Dicken Rocks are more orderly - a roughly continuous vertical face of coarse sandstone cut by joints that divide the face into vertical masses, each perhaps seven meters high and a metre or so wide.

These masses crowd together shoulder to shoulder and most strangely overhang slightly, perhaps because of a harder upper layer. They are striped with cross bedding and in several of the upright blocks this appears to cover a lower, darker overhanging part to give the impression of draped or cloaked faces. The internal structure of the sandstone reinforces the impression of human-like shapes. Even the arc of the cliff turned toward you seems to suggest that the figures are advancing:

A chess-world of topheavy Kings and Queens

Circling in stilted majesty.

Tremble the bog cotton

Under the sweep of their robes

At Dicken Rocks, I read Hughes' translation of Niobe - of the transformation of the woman, the mother, to stone:

Her tongue

Solidified in her stone mouth. Her feet could not move, her hands Could not move: they were stone

Here the transformation of the living woman to stone leaves recognisable human features of 'stone packed in stone'. The image is all the more arresting because the vestiges of the previous state before transformation can be seen, like a palimpsest. At Dicken Rocks 
you are confronted by rock masses that are so uncannily human that Ovid's poem seems to have greater effect, capturing the imagination.

Of course, geologists tend to see the rock and its origin from the point of view of modern science; the features of the ancient environment of deposition, for example. The seemingly 'hooded faces' are erosions of cross-bedded sandstone. We know that this structure formed by deposition on the inclined surfaces of ripples and dunes, indicating a flowing medium - in this case water in the 315 million-year-old 'Kinderscout Grit delta'. We also know that this delta spread from the north and was a river feature the size of the biggest modern deltas. But that's where the comparison ends - this Carboniferous delta would have been unfamiliar to the modern eye, the land around it obviously devoid of animal and human life but also devoid of modern typical plant life, like angiosperm plants.

Perhaps to a Roman reader of Ovid, two thousand years ago, the geological explanation of the origin of the stones of Dicken Rocks might have been harder to accept than an ancient human-to-stone transformation. Which explanation sounds stranger - a river delta in a weird unearthly landscape turned to stone, or people turned to stone?

\section{Stage for the performance of heaven}

The Remains of Elmet is filled with descriptions and images that recall human and animal shapes, and the presences of gods and supernatural forces. In the poem Moors Hughes says that these high plateaux

Are a stage for the performance of heaven Any audience is incidental

On his walks as a boy on the moors above Hebden Bridge, Hughes saw the actors on this stage all around him - the misshapen rocks, the stunted moor trees, the freezing glassy lakes. He imagined dramatic events under the wild sky: titanic struggles and capitulations, murders and kidnappings. This personal mythology, his strange imagination, was informed by ideas from geology and geomorphology, transformed by his interest in non-European cultures and in the 'otherness' of animals.

I read the last of the poems, Moors, to the group as we looked west toward Lancashire at the barren upland of Hare Stones Hill and Black Clough. Reading it aloud in the place where the poem was probably inspired gave the verse a peculiar power. It seemed at least to me for a moment that the moors could be a kind of wild stage and that the rubbly stones that roughened the horizon could be gatherings of ancient, supernatural kings or gods. The audience may have known that the slopes were sculpted by Pleistocene glaciers rather than monsters, and that the upstanding rocks owed their shapes more to joints caused by pressure release than to human transformation. But perhaps for the group, just for a brief instant, it was possible to believe in the transformations of Ovid and Ted

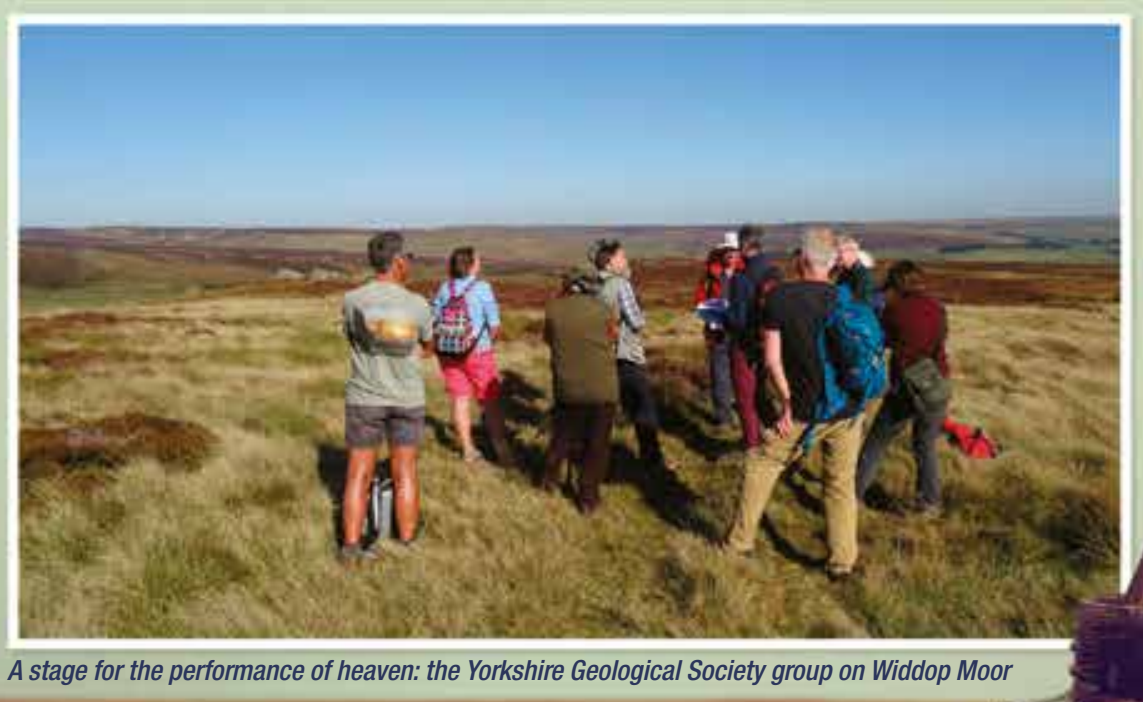

Hughes, and to imagine the landscape through eyes less conditioned by modern science.

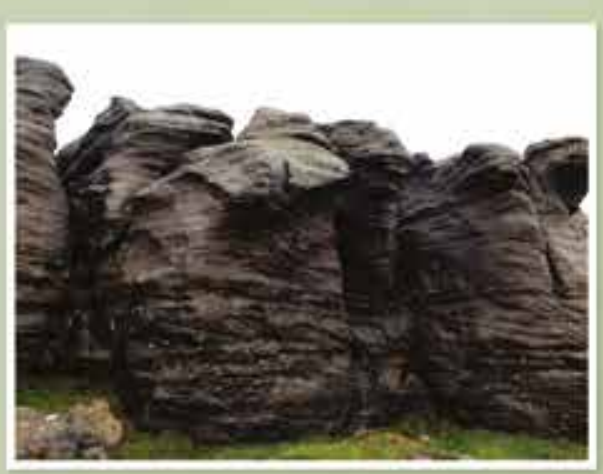

Dickens Rocks: topheavy Kings and Queens

.

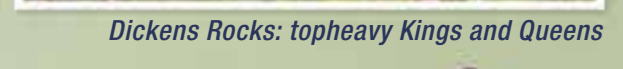

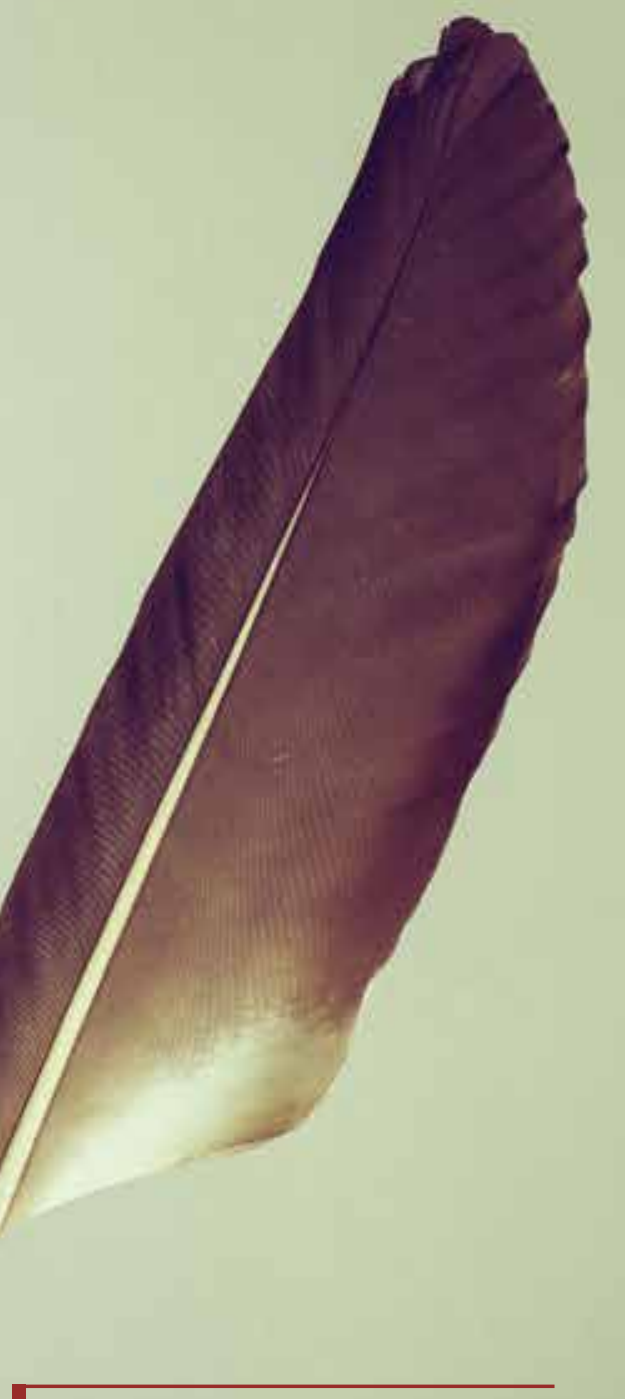

Prof Mike Stephenson is Executive Chief Scientist at the British Geological Survey.

Email: mhste@bgs.ac.uk. 


\section{Polymath extraordinaire}

\section{Geologist and science writer Nina Morgan explores the lesser known side of John Ruskin}

\section{ohn Ruskin [1819 - 1900] is best known as an artist, critic, philanthropist and social reformer.} But his first love was geology. As a child Ruskin's geological interests were awakened by the Scottish landscape. Early on, though, it was mineralogy that really captured his imagination. As he recalled in his book Deucalion, a collection of his geological writings published in 1875:

"..indeed, I began when I was only twelve years old, a Mineralogical Dictionary intended to supersede everything done by Werner and Mohs, (and written in a shorthand composed of crystallographic signs now entirely unintelligible to $\mathrm{me}$ )."

By the age of 15 Ruskin had already begun publishing geological essays in London's Magazine of Natural History. Although he went up to Christ Church College, Oxford in 1837 to study classics, a month after his arrival Ruskin enrolled in William Buckland's [1784 - 1856] lectures on mineralogy. In spite of the fact that each series of lectures cost his father an additional fee of up to two guineas, he attended all of Buckland's lectures on mineralogy and geology throughout his student years, and produced drawings for many of them. In a letter to Buckland dated 4 November 1837 Ruskin's father thanked Buckland for the 'attentions you have so kindly bestowed on him [Ruskin]' and offered 'my best thanks for these attentions to my Son'.

\section{Joining the Geological Society}

In 1840 Ruskin was elected a Fellow of the Geological Society, and remained a Fellow for the rest of his life. Interestingly, although by the late 1850s Ruskin had become very interested in social reform he doesn't appear to have ever joined the Geologists' Association. This organisation, established in 1858 and open to all 'to enable the practical student in Geology to find a congenial place where doubts may be stated and experience exchanged' might have seemed to be a natural home for someone interested in promoting the education of 'the workmen and labourers of Great Britain'.

Writing in QJGS his obituarist noted that:

"His career and his great services to art and to literature have been recorded in many publications; but we must not forget his services to our science, in directing the attention of artists and others to the effect of geological structure and of the characters of rocks on scenery. This is especially exemplified in what is, perhaps, his greatest work, Modern Painters, and I would refer to four chapters of vol. i, entitled Truth of Earth (pp. 265319), and to the magnificent fourth volume, devoted to Mountain Beauty, eleven chapters of which on the 'Materials of Mountains/ Sculpture of Mountains, and Resulting Forms (pp. 107-324) might be read with advantage by many geologists."

\section{Failed ambition}

In spite of his many achievements and influential writing on many subjects, later in life Ruskin expressed some regret for not having followed up his "natural disposition for these sciences [geology and botany] [that] would certainly long ago have made me a leading member of the British Association for the Advancement of Science". And although Ruskin revealed in Deucalion that throughout his life he endeavoured "to keep abreast with the rising tide of geological knowledge; sometimes even, I believe pushing my way into little creeks in advance of the general wave", his Geological Society obituary records that 'he contributed no paper to this Society'. History records that neither did Ruskin achieve what he described in Deucalion as: "the position which it was always the summit of my early ambition to attain, that

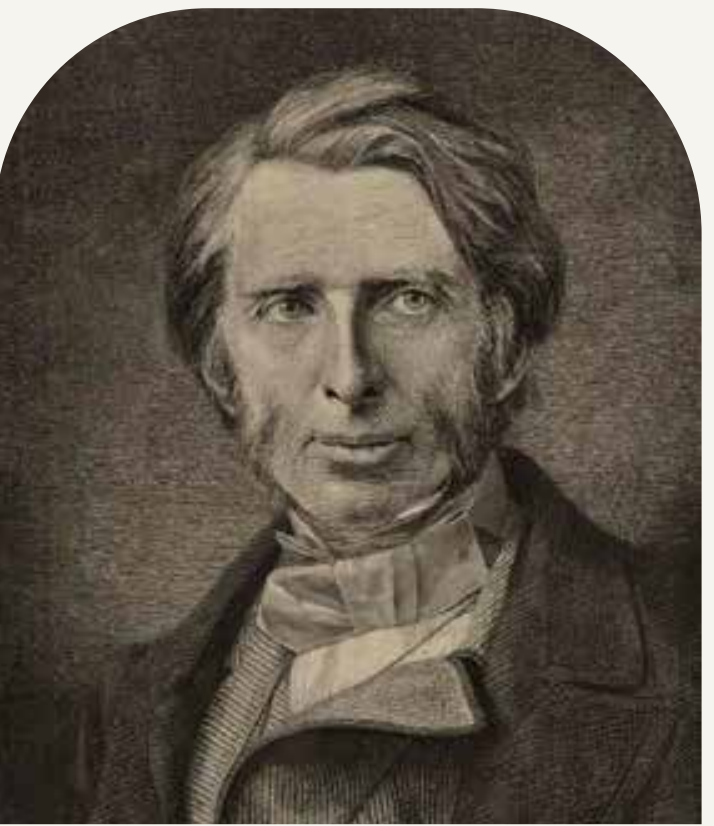

John Ruskin (1819-1900), engraving by Henry Sigismund Uhlrich (1846-1937). Llyfrgell Genedlaethol Cymru - The National Library of Wales (public domain).

of President of the Geological Society".

End notes: Sources for this vignette include: A review of the free exhibition at Two Temple Place, London, 26 Jan - 22 April 2019, celebrating the cultural and social heritage of the Victorian polymath John Ruskin (Geoscientist Books \& Arts online 2019 available at www.geolsoc.org. uk/Geoscientist/books-arts/2019-reviews/ Ruskin-Exhibition); Louise Pullen, Ruskin on Rocks, Art, Mountains and Mineralogy Sheffield Galleries and Museums Trust, 2006; Van Akin Burd, Ruskin and His 'Good Master,' William Buckland, Victorian Literature and Culture 36, no. 2, 2008, pp. 299-315. Available at https://www. jstor.org/stable/40347189; G.S. Sweeting , The Geologists's Association, a History, Benham and Company, 1958. I thank Wendy Cawthorne for sending me the text of Ruskin's obituary published in QJGS 56, pp Ix - Ixi, 1900.

* Nina Morgan is a geologist and science writer based near Oxford. Her latest book, The Geology of Oxford Gravestones, is available via www.gravestonegeology.uk 


\title{
Fossil 'Buckyball' structures found in Cretaceous crinoids
}

\author{
Fossil Buckminsterfullerene-type structures, colloquially known as 'buckyballs', have been discovered in \\ Cretaceous crinoids at the Sedgwick Museum, writes Douglas Palmer
}

The find was made by palaeobiologists Jennifer Hoyal Cuthill and Aaron Hunter, who carried out a quantitative analysis two species of aberrant echinoderms commonly known as sea lilies.

The analysis reveals that their hollow ballshaped tests, built of numerous calcareous plates, have structural similarities to fullerenetype structures, more commonly associated with complex carbon molecules.

Buckminsterfullerenes, or 'buckyballs', are a particular kind of geometrical structure named after the American architect

Buckminster Fuller, who patented the thin-shelled but structurally rigid geodesic dome - used in such iconic structures as the cold war radar domes of the Arctic DEW line and the more peaceable Eden Project in Cornwall. The possibility of creating such hollow spheres at the molecular scale using carbon atoms was first hypothesised in the late 1960s, then synthesised and finally found to occur in natural materials from soot to cosmic dust and viruses.

Now for the first time, macroscopic 'buckyball' structures have been found in two species of 80 million year old fossils crinoids, Uintacrinus socialis and Marsupites testudinarius, which belong to a superfamily of extinct stemless crinoids called the Uintacrinoidea. These strange, vaguely plant-like animals are actually echinoderms related to starfish and sea urchins, as can be seen from the vestiges of their five-fold body symmetry. The most characteristic features of these uintacrinoids are their long feeding arms and football-shaped calyx, constructed from calcium carbonate plates.

Of the two species, U. socialis has the more expanded calyx with numerous small plates with between 4 and 8 sides. This expanded calyx is thought to have functioned either as a stabiliser on the soft chalk muds of the seafloor, or as a buoyancy chamber, which allowed the crinoid to float in the seawater. In comparison, the calyx in $M$. testudinarius has fewer (16) but relatively large plates, each with 5-6 sides.

Geometrical analysis has been carried out by Jennifer Hoyal Cuthill, now a research fellow at the University of Essex, and Aaron Hunter, an adjunct Research Fellow at the University of Western Australia. Their analysis shows that the resulting plate structure of the calyx in $M$. testudinarius is identical to a stable and strong carbon fullerene. In contrast the structure of $U$. socialis does not allow such a stable configuration and was more prone to buckling and therefore predation.

The analysis further suggests that this strong buckyball-like structure provided an evolutionary advantage in the increased calyx strength and stability seen in $M$. testudinarius, compared to the increase in plates and calyx size but reduced stability seen in U. socialis. However, this advantage was to prove temporary, since both uintacrinoid species became extinct by Late Campanian times when new marine predators, such as crabs, evolved.

The research used uintacrinoid specimens from the collections in the Sedgwick Museum, where they are on display.

Douglas Palmer is Communications Officer at the Sedgwick Museum of Earth Sciences, Cambridge

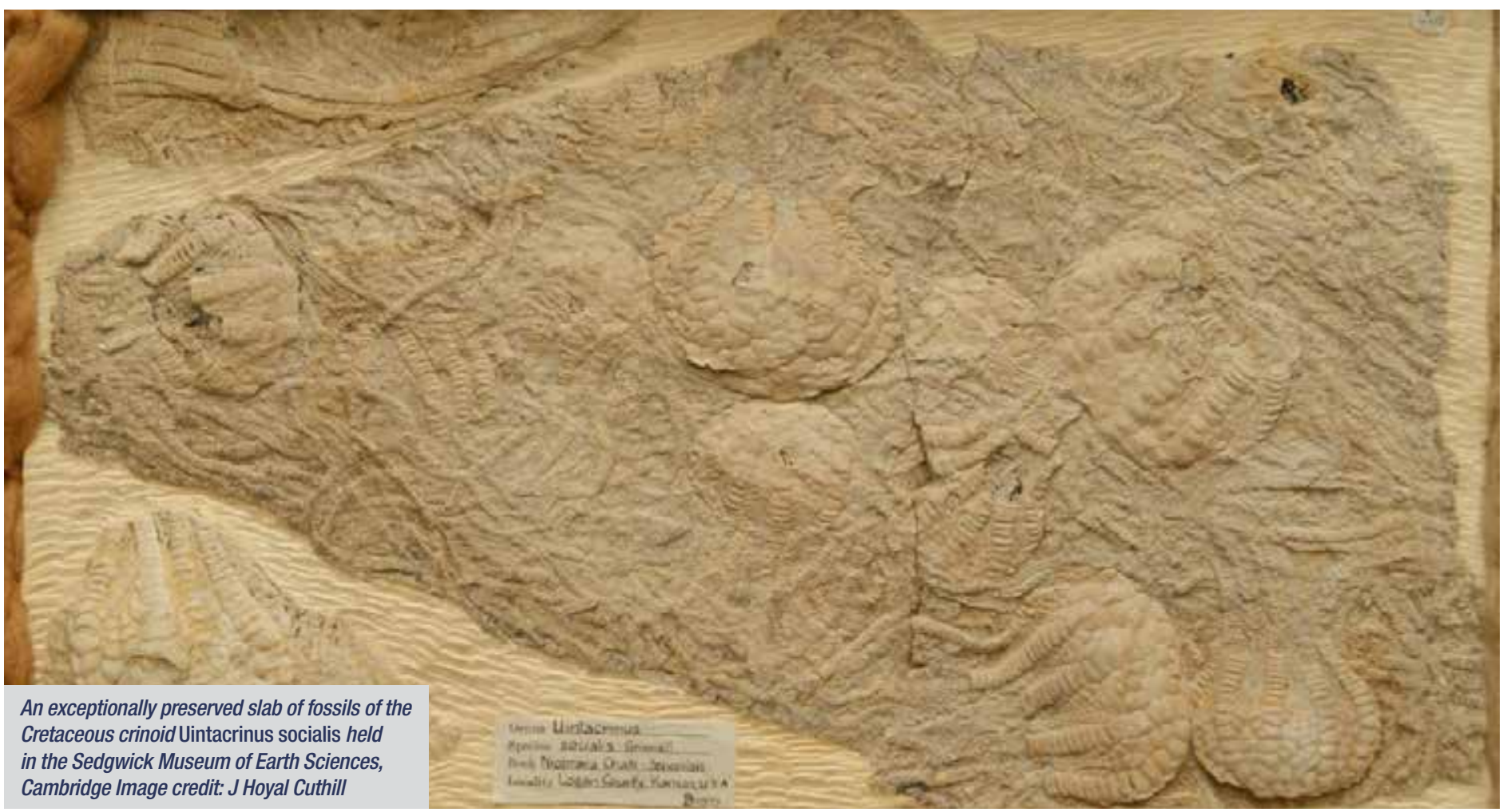




\section{Mary Anning Rocks}

\section{Evie Swire and Anya Pearson on a campaign to establish a statue and a learning legacy for a palaeontological pioneer}

When I asked Evie, my twelve year old daughter and the founder of Mary Anning Rocks, if she'd like to help me write a few words for Geoscientist magazine, the first thing she said was 'Do they actually know who Mary Anning is, because if they did that would be really nice mummy, not having to explain all the time who she is?'

I agree - it's so refreshing to write for an audience who likely already know just how amazing this woman was, and why she should be remembered and celebrated. Just in case you didn't: Mary Anning was a pioneering palaeontologist and fossil collector, born in 1799 in Lyme Regis. Despite her lack of a formal education, her discoveries changed the way we think about the planet and how life evolved.

I'll be honest, until I moved from London to Dorset 14 years ago, I didn't have a clue who she was. l'd spent many a summer holiday fossicking on Charmouth beach as a kid in the 80s, yet never once did I hear her name mentioned - she just didn't exist!

Fast forward a few decades and things have slowly changed. The biggest breakthrough came when Mary Anning was added, by name, to the National Curriculum in 2015. Now all key Stage 1 and 2 children learn all about her. Every summer without fail, you see 7 and 8 year old children in their droves, towing their parents around Charmouth and Lyme Regis on epic fossil hunting trips - a direct result of Mary's voice and narrative being included in the classroom.

\section{The campaign}

It really started just over two years ago when an indignant Evie discovered that there was no statue of her hero Mary Anning in her home town of Lyme Regis - our campaign exists to make that happen. We think it's hugely important to acknowledge and honour Mary in a visual way, giving her a physical presence in Lyme Regis, and making sure the people that live in Dorset and the thousands of tourists that come to visit every year have a focal point of remembrance and respect.

And thanks to her inclusion in the National Curriculum, the next generation of Earth Scientists will have Mary well and truly in their memory banks, but we want to do more. It's the cavernous gap between an educated few and the wider public we want to tackle - and that's where Mary Anning Rocks: A statue for Mary comes in.

\section{'You can't be what you can't see'}

Evie and I love that quote. It's by an American activist, Marian Wright Edelman, who champions the rights of children. If we don't keep visualising for children, offering role models for them to look up to and celebrate - especially the women who have been written out of history - then what future can we expect for the next generation?

We've been overwhelmed by the support we've received so far, including from the likes of Sir David Attenborough, Tracy Chevalier (author of 'Remarkable Creatures'), and Professor Alice Roberts. So come on and join our global 'Anning Army' now, and help us raise the cash needed to raise a statue for this unsung and forgotten palaeo pioneer Mary Anning truly does ROCK!

Find out more about the Mary Anning Rocks campaign at www.maryanningrocks.co.uk. Registered Charity Number 1188919
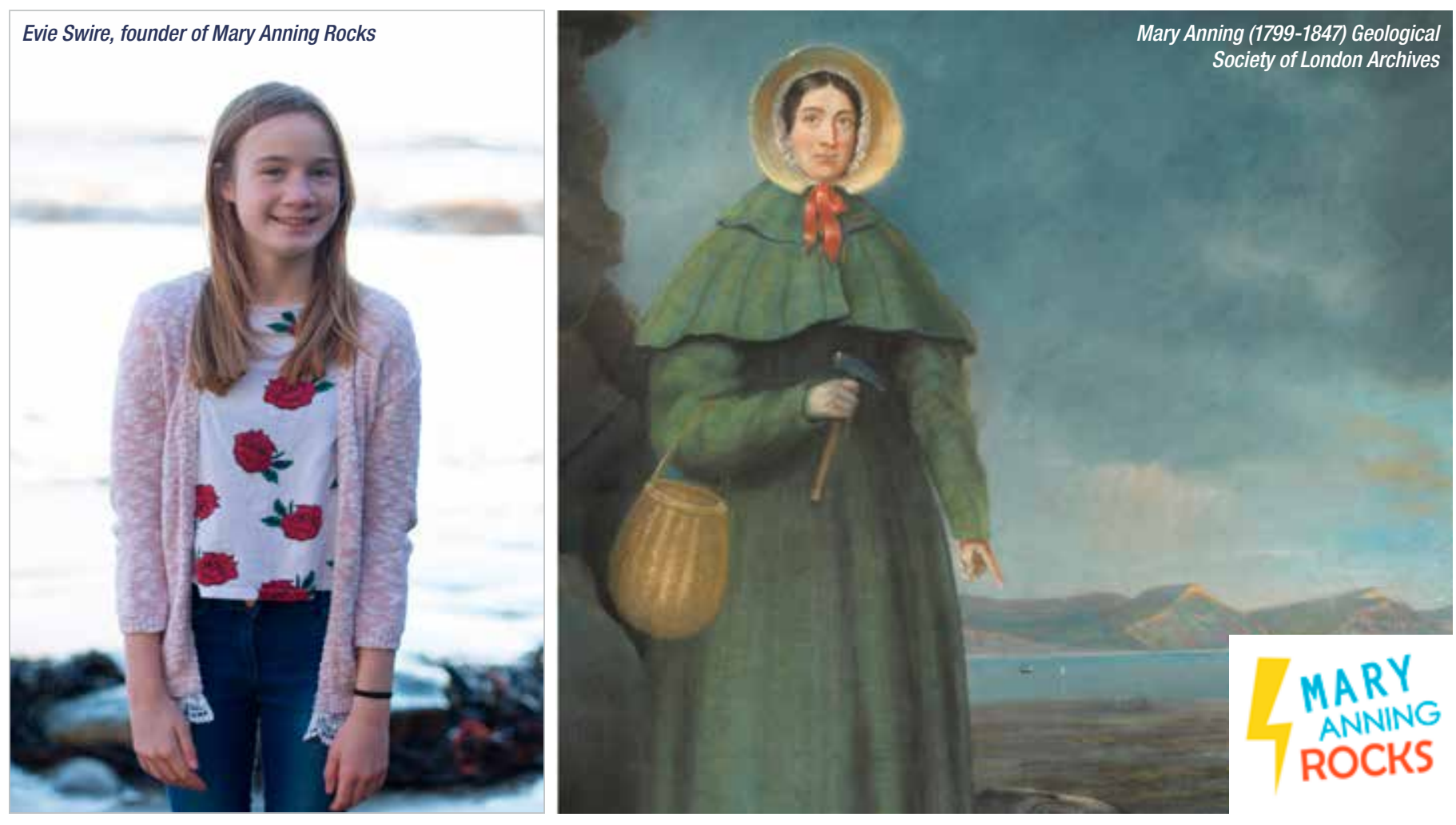
Geoscientists in the news and on the move in the UK, Europe and worldwide

\section{Crossword}

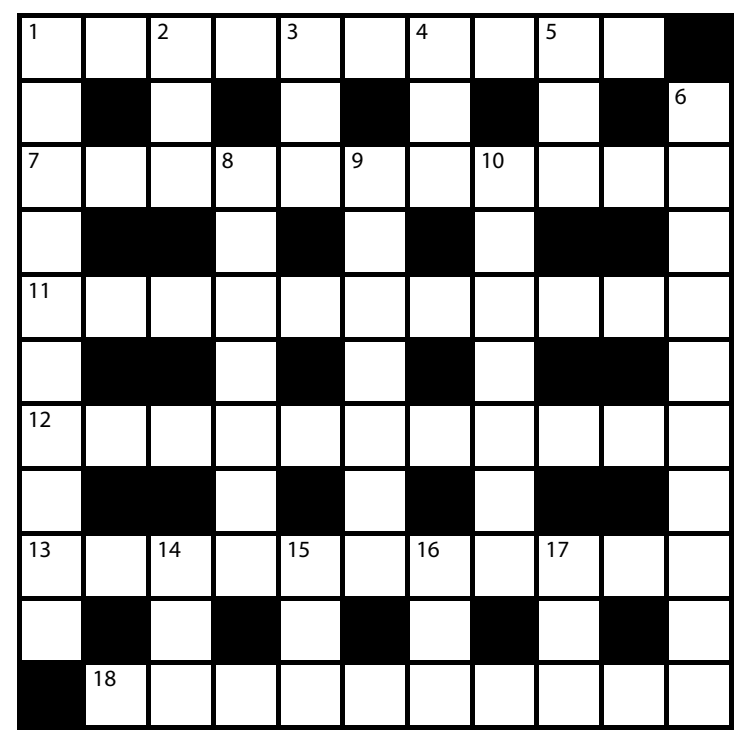

\section{Across}

1 An oxide of thorium and uranium (10)

7 Pigment made from lazurite (11)

11 The arrowroot family (11)

12 Feature of clothing covering the arms (4-7)

13 Operations cutting or desensitizing nerves (11)

18 Often readers of Geoscientist (10)

\section{Down}

1 Rubellite is a red or pink variety (10) 2/14 An angle between 90 and 180 degrees (6)

3/4 The common galaxias (6)

5 Prefix meaning three (3)

6 Possibly, people who study fairy tales (10)

8 Arsenic monosulfide (7)

9 Colloquially a sailor (7)

10 North American tree that produces corky growths $(4,3)$

14 See 2

15/16 A semi-oxidized Chinese tea (6) 17 Often, accompanied by 'buts' (3)

Solutions April | Across: 6 cerci 7/27 Goya 10 Courtauld 11 hrs 12 D'aeth 14 rpm 15 Riley 18 Rymill 20/22d nerite 21 omni- 23 Naas 26 MST 28 cumulate Down: 1 Wager 2/8A to-do 3 Scott 4 trout 5 Lindsay 8 do-re-mi 9 oust 10 Chapman 12 dry 13/1 A Gino Watkins 16 lemma 17 Ernst 18 ruby 19 luau 24 Ac $25 \mathrm{Sm}$

\section{STieks AND STONES}

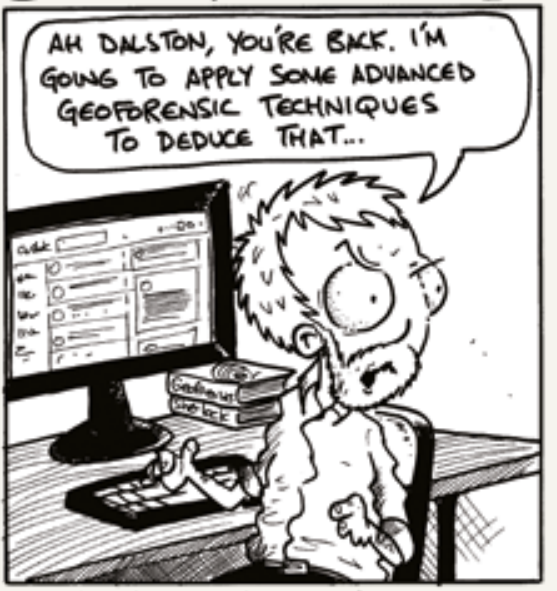

www, stonechatproductions.co.uk

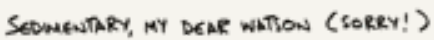

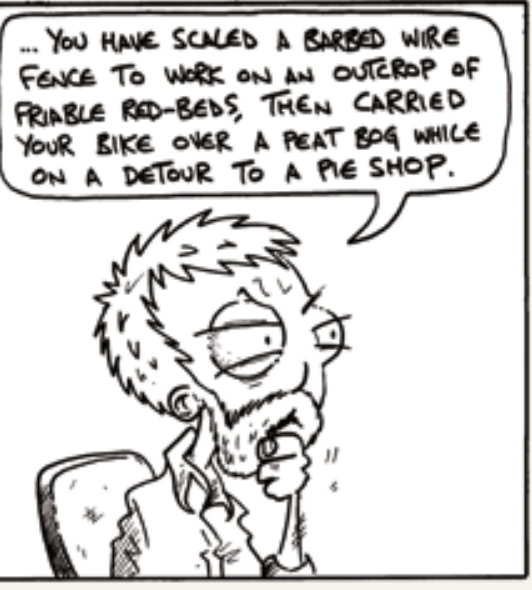
Fave To wate on an ovtcrop of FRIABLE RAD-BEDS, THEN CARRIED YOUR BIKE OVGR A PEAT BOG WHILE ON A DETOUR TO A PIE SHOP.

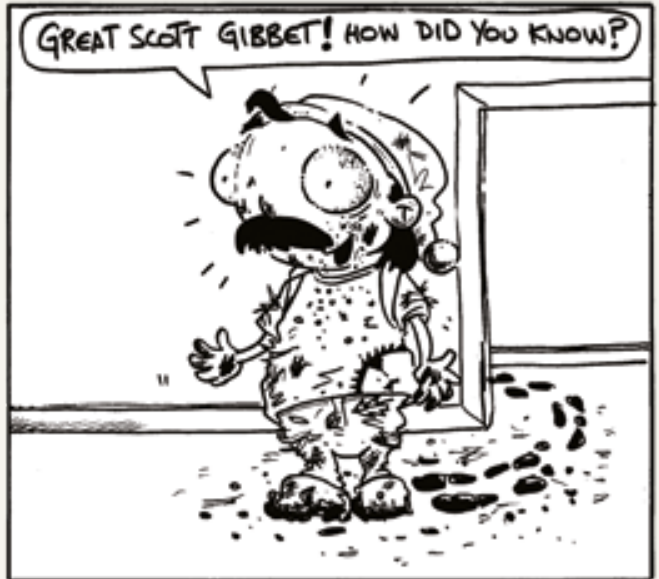

Don $05 / 2020$
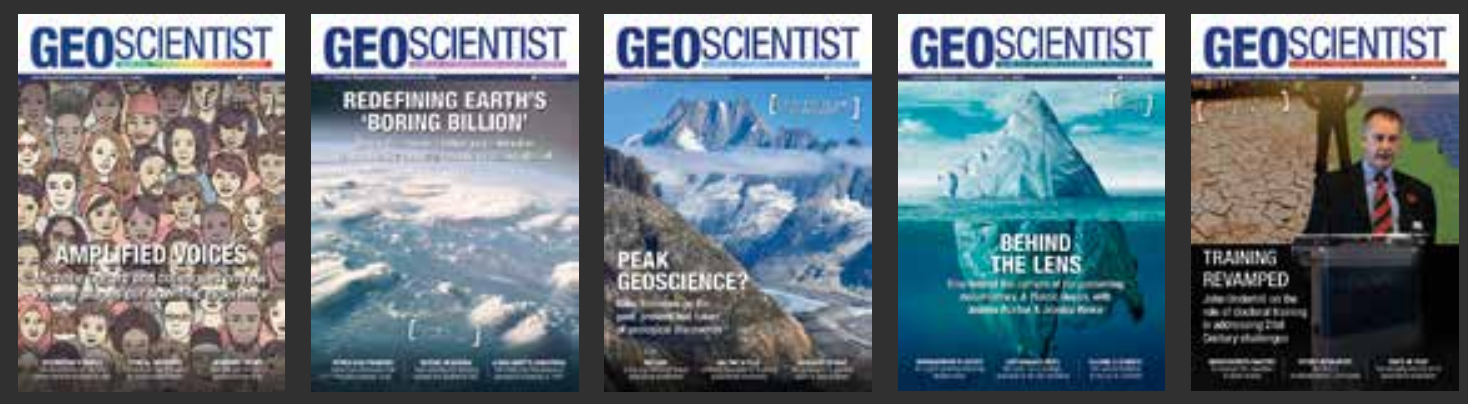

Read the latest news in Geoscientist, when you join the GSL 
The

Geological Society

serving science, profession $\mathcal{E}$ society

HERIOT Scottish

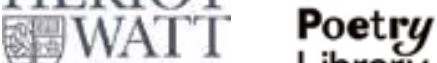
UNIVERSITY Library

\section{October 2020}

\section{Activities Include:}

- Geopoetry Walk past Dynamic Earth and on to Arthur's Seat (Geology and Poetry in the field) Yvonne Reddick (UCLancs).

- Schools Geopoetry competition winners.

- Poets and Geologists telling their stories about rocks, poems and influences interspersed with readings (SPL) with contributions by Sarah Acton (Poet in Residence, Jurassic Coast), Michael McKimm (Geological Society) and Norman Bissell (Scottish Centre for Geopoetics).

- Geopoetry Workshop: individuals present poems for discussion and feedback.

- Edinburgh/Scottish Poets with geological gifts, Ken Cockburn (Edinburgh Poetry Tours), at Panmure House.

\section{Organising Committee}

Patrick Corbett, Heriot-Watt University

[p.w.m.corbett@hw.ac.uk]

Stuart Harker, Consultant

Phil Ringrose, Equinor/NTNU,

Norway

Michael McKimm

Bob Gatliff

Asif Khan, Scottish Poetry Library Tom Kelly, Central Scotland

Regional Group

Carol Cotterill, BGS

Dorrik Stow, Heriot-Watt University Lara Reid, Friends of Hugh Miller Society

Norman Bissell, Scottish Centre for Geopoetics

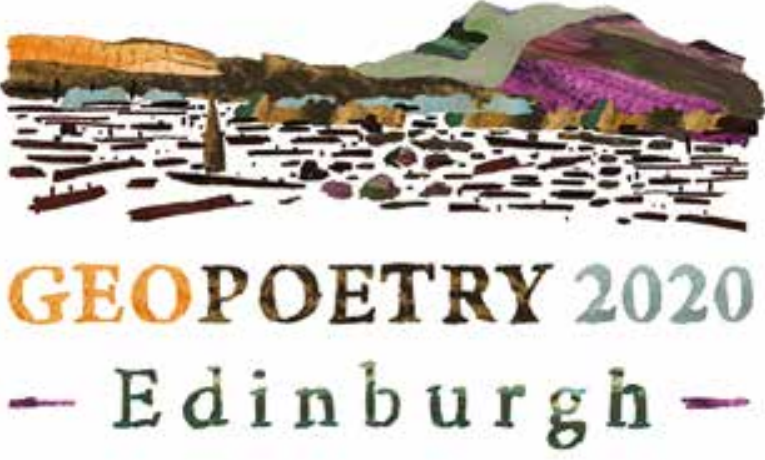

\section{The Scottish Poetry Library and its environs, Edinburgh}

This event is to follow up the first Geological Society of London's GEOPOETRY day in 2011. Rocks have long inspired poets (refer to Burns' "O my Luve's like a red, red rose" poem of 1794):

\footnotetext{
"Till a' the seas gang dry, my dear,

And the rocks melt wi' the sun"
}

To the present day poets are similarly inspired. Michael McKimm's Fossil Sunshine (2013) and "MAP, Poems after William Smith's Geological Map of 1815" (2015) showed how geological subject matter from Geopoetry 2011 could inspire poets: "...the poems here make Smith's map anew in moving and surprising ways." The Jurassic Coast Poems (2017) by Sarah Acton, the Jurassic Coast resident poet, shows continued inspiration:

$$
\begin{aligned}
& \text { "We hear the red rock } \\
& \text { Speak in ripples" }
\end{aligned}
$$

This gathering, to be held on National Poetry Day (1st October, 2020) is hosted by the Geological Society of London (in conjunction with the Central Scotland Group), The Scottish Poetry Library and the Edinburgh Geological Society and will bring together poets and geoscientists to further encourage the rocks to speak.

\section{Proposed themes and activities}

The organisers will be seeking contributions, which will form the basis of a programme of talks, walks, readings and workshops and ultimately a publication, in the following areas:

- Geo-themes: poetry about rocks, geologists, geological sites

- Geo-images: poetry that uses earth and ocean images

- Geology and Society: poetry drawn from earth and society interaction

- Geoscience and the poetic form: Geopoets' influences, inspirations, histories

These are to be submitted to the Geological Society by 1st March, 2020. English language translations must be provided for poems in different languages. More details on the submission process will be available in autumn of 2019.

www.geolsoc.org.uk/geopoetry20

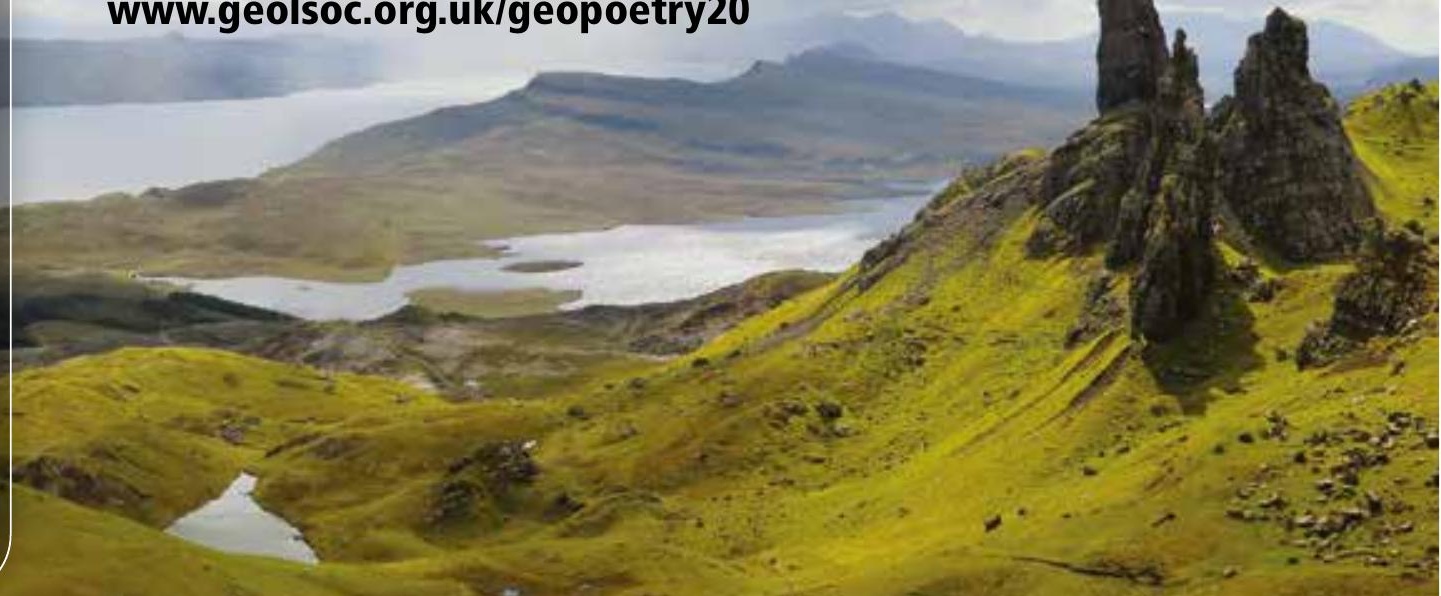




\section{OBITUARY lain Ashworth Williamson 1931-2019}

$\mathrm{I}$ ain Ashworth Williamson passed away 1 peacefully on Saturday November $2^{\text {nd }}$ after a short illness. He remained very active until recent months and often enjoyed his walks around Ambleside and then Kendal, where he was resident in his final months.

Iain attended Burnley Grammar School from 1942 - 1950 and Nottingham University from 1955 - 1958, graduating with a B.Sc in Geology and in 1960 with an M.Sc.

\section{Travel and research}

From an early age, Iain always had a passion for field geology and enjoyed all aspects of mountaineering, maps and history, spending many happy hours immersed in books. He travelled to many parts of the globe, as part of his work and research - including some very remote parts of the South Americas. Iain was a very accomplished golfer and declined the chance to turn professional in favour of his studies.

Iain was devoted to Pat (nee Holt), his wife of 60 years and was the proud father of Roger and Katie and grandfather to Ross, Bill, Ambrose \& Digby. His son Roger followed in his footsteps as a geologist, until his death in 2010.

\section{Memberships and publications}

He was elected as a Fellow of The Geological Society in 1953, then a Senior Fellow and an Industrial Fellow from 1958 - 1998. He was

\section{Highly sought after geological consultant with a passion for field geology and travel}
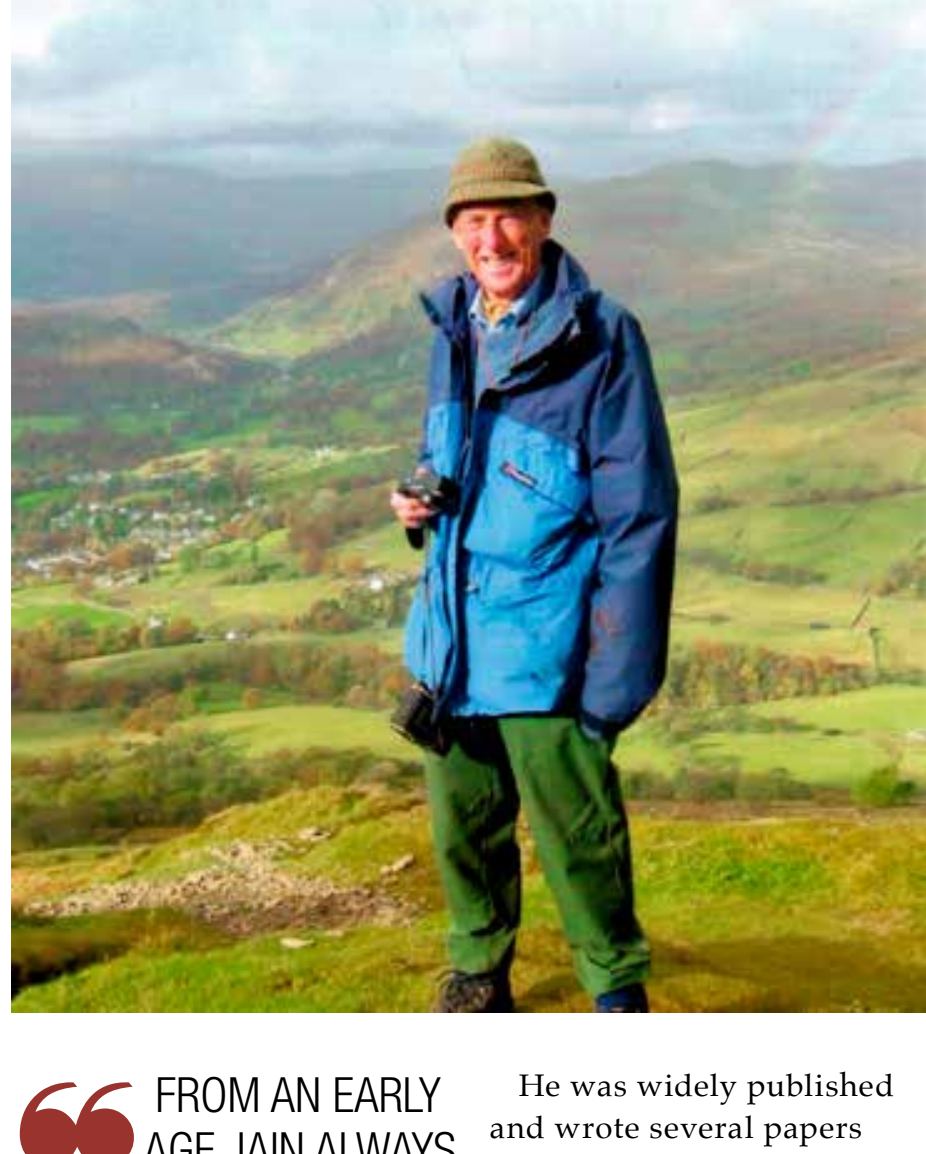
FROM AN EARLY AGE, IAIN ALWAYS HAD A PASSION FOR FIELD GEOLOGY AND ENJOYED ALL ASPECTS OF MOUNTAINEERING, MAPS AND HISTORY, SPENDING MANY HAPPY HOURS IMMERSED IN BOOKS

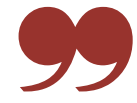

also a member of the Manchester Geological Association from 1951, the Lancashire Group of the Geologists' Association from 1950, the Yorkshire

Geological Society from 1950 and the Institution of Mining Engineers from 1965.
He was widely published and wrote several papers over the last 50 years including several, often referenced, early papers on Tonsteins - and was the author of 'Coal Mining Geology', published in 1967.

He was a Senior Lecturer at The Wigan Mining College very successful and highly sought-after geological consultant since the early 1970s.

In his own words: 'My most fundamental belief is in there being a God to whom all natural things belong. Please ask folk not to grieve - and remember me when the wind blows in your face and when you are walking in a blizzard and enjoying the from 1958 - 1980 and was a sensation of nature.

'I'm now on my next and probably my greatest adventure.

By Mark Witherspoon

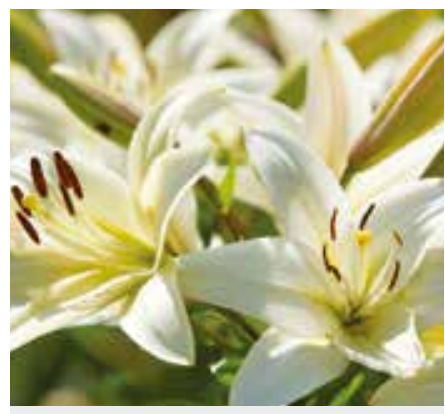

The Society notes with sadness the passing of:

Ashworth, Kevan*

Brooks, John*

Cambray, Frank W*

Chambers, Henry*

Donovan, Desmond ${ }^{\star}$

Glennie, Ken

Hunt, Albin Digby ${ }^{\star}$

Holland, Charles

James, Ella*

King, Cuchlaine*

Morey, Colin Robert

Pascall, Carolyn*

Potter, John F

Reading, Harold

Rhodes, Frank ${ }^{\star}$

Snelling, Norman John

Urquhart, Elspeth

Walton, Derek*

Williamson, lain

In the interests of recording its Fellows work for posterity, the Society publishes obituaries online, and in Geoscientist.

Bold, recent additions to the list; * Fellows for whom no obituarist has been commissioned; $\S$ biographical material lodged with the Society.

If you would like to contribute an obituary, please email sarah.day@geolsoc.org.uk to be commissioned. You can read the guidance for authors at www.geolsoc org.uk/obituaries. To save yourself unnecessary work, please do not write anything until you have received a commissioning letter.

Deceased Fellows for whom no obituary is forthcoming have their names and dates recorded in a Roll of Honour at uww.geolsoc.org.uk/obituaries. 


\section{OBITUARY Alastair Charles Lumsden (1937-2019)}

$\mathrm{A}$

lastair Lumsden sadly died aged 81 on $22^{\text {nd }}$

July 2019, after a short illness. He was a great man, an engineering geologist par excellence.

Alastair attended the Royal Grammar School, Newcastle, from 1949-1956, where he was renowned for his sporting prowess, particularly on the rugby field.

He graduated in Geology from Durham University in 1961 and subsequently went off to Australia to the Geological Survey of Queensland (19631966), conducting regional and local hydrogeological surveys and engineering geological investigations throughout the State.

From 1968 to 1970 he worked as a Senior Hydrogeologist and Resident Engineer for groundwater investigation for the Lar Dam project in Iran. Following his return to the UK Alastair became a lecturer/ senior lecturer in engineering geology at Trent Polytechnic (1970-1974); he also completed an MSc in hydrogeology by research at Newcastle University during this period.

\section{Revitalising the Leeds MSc in Engineering Geology}

Subsequently, in 1975, Alastair moved to Leeds following the sad death of Alan Gaskin. Here he re-vitalised the MSc in Engineering Geology. By the time I got there in 1984, the course was thriving, gaining plaudits and NERC scholarships - I recall that we had six which was a mighty achievement compared to our colleagues at Imperial,

Durham and Newcastle. He

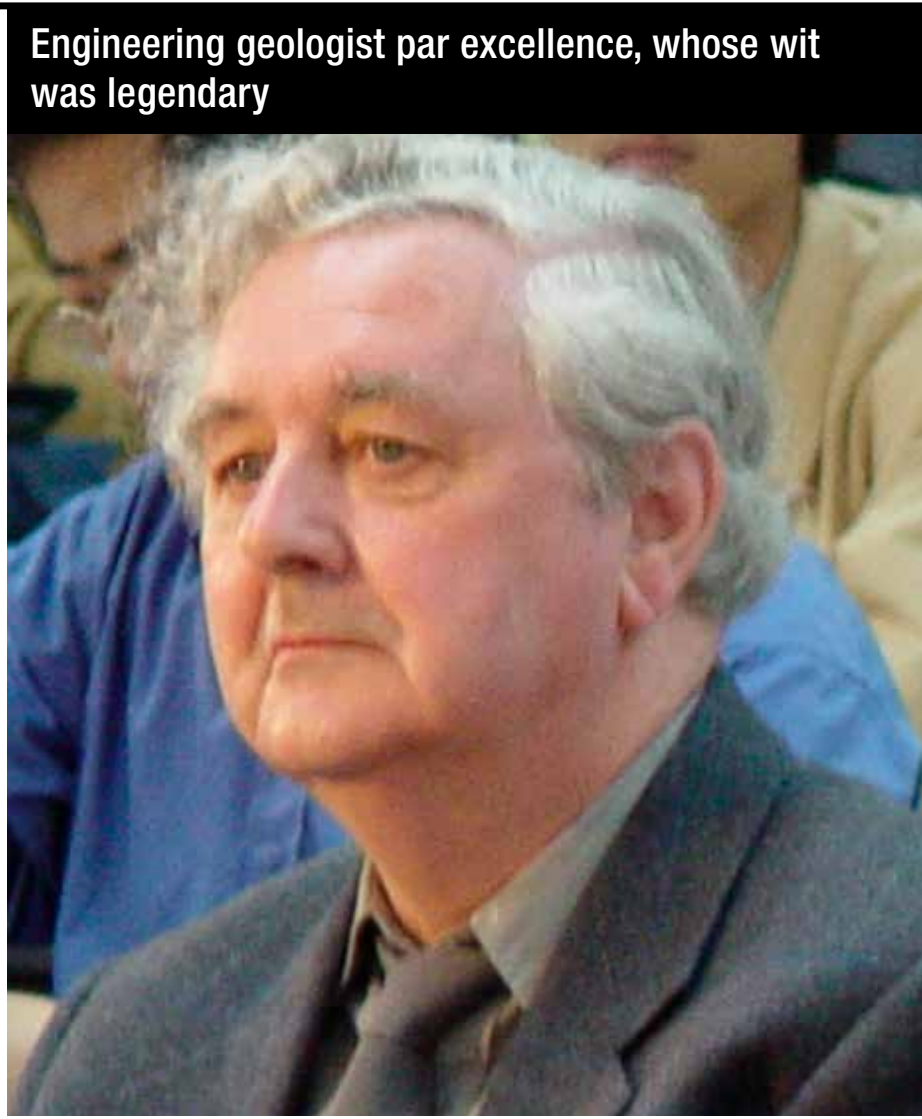

had already graduated Doug Stead and Martin Culshaw and had a PhD student, Stavros Bandis, whose research was awarded the Manuel Rocha prize of the ISRM. This research resulted in the publication of a classic scientific work "Fundamentals of Rock Joint Deformation" by Bandis, Lumsden and Barton - which has received over 1700 research citations. Research continued with Altay Acar (Turkey), Abbas Al Harthi (Saudi Arabia), Qui Hong Liao (China), Theo Papaliangas (Greece) and numerous UK students - to name a few, Simon Welsh, Keith Rawnsley, Dawn Nicholson, Chris Power and Jared West, who is now Deputy Head of School at Leeds. was causing it!"

He was a stickler for grammar; no split infinitives here. When he retired, he took on the role of Editorial Manager of the Journal of Petrology to assist his wife Marjorie. He worked full time in this role until the age of 80 - putting his talents to good use.

Alastair's legacy will always be the MSc in Engineering Geology at Leeds. He built the course from scratch, teaching it using the three verbal equations of engineering geology that he developed with Professors David Price (Delft) and Sir John Knill. Sir John, by the way, was a regular visitor at Leeds, enjoying fish and chips at Alastair's favourite restaurant, Bryan's, in Headingly. When I was there the numbers were typically 10 to 20 students per year; now they are up to 36 , taught by Bill Murphy, Jared West, Mark Thomas, Mark Hildyard (another Manuel Rocha prize winner), Antonio Abellan Fernandez and Chrysothemis Paraskevopoulou. Long may the MSc course continue to flourish.

Alastair was married three times. His first marriage to Margaret ended in divorce, and his second wife Jean sadly died of breast cancer in 1986. He is survived by his wife of 23 years, Marjorie Wilson, Emeritus Professor of Igneous Petrogenesis at Leeds, and by the three children of his first marriage, Michael, Karen and Iain. someone like you, with a penchant for research, would have by now figured out what

By Steve Hencher 


\section{Year of Life Collection}

The evolution of life on Earth has been intrinsically linked to the planet's climatic and biogeochemical state for several billion years. From microbes living deep in the crust to Himalayan tardigrades, and from the search for life's origins to predicting the future climate, life has occupied, adapted to and shaped virtually every environment with impacts across the breadth of the geosciences. This collection, part of the Society's Year of Life 2020, aims to collate recent and seminal papers that cover the breadth of geoscience research into the impacts, or the effects of, life on Earth and beyond. Reconstructing ecosystems from the Archaean to the Anthropocene, mass extinctions to the actions of microbes, and from deep sea vents to astrobiology.

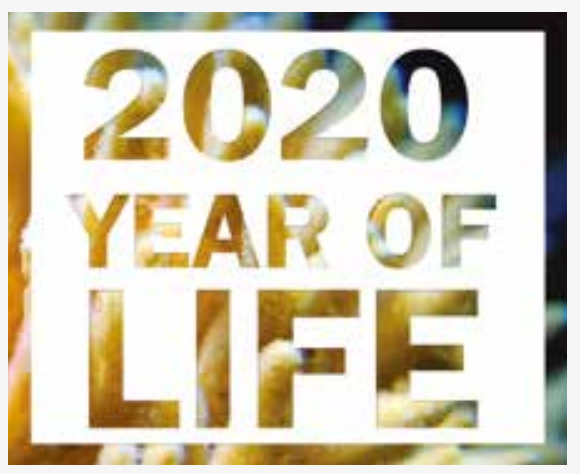

\section{Collection Guest Editors}

Heda Agić, University of California Santa Barbara, United States of America

William Foster, University College Dublin, Ireland

Sophie Nixon, University of Manchester, United Kingdom

Sean McMahon, University of Edinburgh, United Kingdom

Duncan Murdock, Oxford University Museum of Natural History, United Kingdom

\section{View the collection at www.lyellcollection.org/cc/year-of-life-collection \\ Find out more about the Year of Life www.geolsoc.org.uk/life20}


NCS

EXPLORATION

RECENT DISCOVERIES 2020 ncs-exploration.com

\#ncsexploration

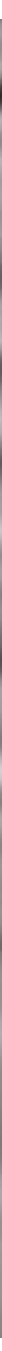

ECHINO SOUTH - EQUINOR

SHREK - PGNIG

DUVA - NEPTUNE ENERGY

IRIS/HADES - OMV

GLENGORM - CNOOC

GOLIATH WEST - VÅR ENERGI

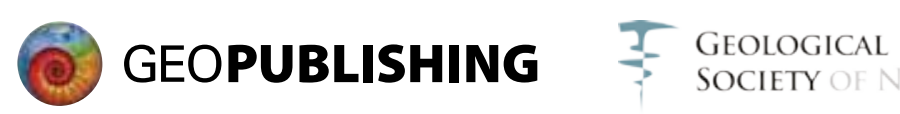

